\title{
Seasonal dissolved inorganic nitrogen and phosphorus budgets for two sub-tropical estuaries in south Florida, USA
}

\author{
C. Buzzelli ${ }^{1}$, Y. Wan ${ }^{1}$, P. H. Doering ${ }^{1}$, and J. N. Boyer ${ }^{2}$ \\ ${ }^{1}$ Coastal Ecosystems Section, South Florida Water Management District, West Palm Beach, Florida 33406, USA \\ ${ }^{2}$ Center for the Environment and Department of Environmental Science and Policy, Plymouth State University, 17 High \\ Street, MSC \#63, Plymouth, New Hampshire 03264, USA
}

Correspondence to: C. Buzzelli (cbuzzell@SFWMD.gov)

Received: 3 January 2013 - Published in Biogeosciences Discuss.: 11 February 2013

Revised: 18 September 2013 - Accepted: 25 September 2013 - Published: 24 October 2013

\begin{abstract}
Interactions among geomorphology, circulation, and biogeochemical cycling determine estuary responses to external nutrient loading. In order to better manage watershed nutrient inputs, the goal of this study was to develop seasonal dissolved inorganic nitrogen (DIN) and phosphorus (DIP) budgets for the two estuaries in south Florida, the Caloosahatchee River estuary (CRE) and the St. Lucie Estuary (SLE), from 2002 to 2008. The Land-Ocean Interactions in the Coastal Zone (LOICZ) approach was used to generate water, salt, and DIN and DIP budgets. Results suggested that internal DIN production increases with increased DIN loading to the CRE in the wet season. There were hydrodynamic effects as water column concentrations and ecosystem nutrient processing stabilized in both estuaries as flushing time increased to $>10 \mathrm{~d}$. The CRE demonstrated heterotrophy (net ecosystem metabolism or NEM $<0.0$ ) across all wet and dry season budgets. While the SLE was sensitive to DIN loading, system autotrophy $(\mathrm{NEM}>0.0)$ increased significantly with external DIP loading. This included DIP consumption and a bloom of a cyanobacterium (Microcystis aeruginosa) following hurricane-induced discharge to the SLE in 2005. Additionally, while denitrification provided a microbiallymediated $\mathrm{N}$ loss pathway for the CRE, this potential was not evident for the SLE where $\mathrm{N}_{2}$ fixation was favored. Disparities between total and inorganic loading ratios suggested that the role of dissolved organic nitrogen (DON) should be assessed for both estuaries. Nutrient budgets indicated that net internal production or consumption of DIN and DIP fluctuated with inter- and intra-annual variations in freshwater inflow, hydrodynamic flushing, and primary production. The results of this study should be included in watershed man-
\end{abstract}

agement plans in order to maintain favorable conditions of external loading relative to internal material cycling in both dry and wet seasons.

\section{Introduction}

Estuaries modulate the inputs of water and materials from the watershed to the coastal ocean through intense internal biogeochemical cycling. Water column concentrations of carbon $(\mathrm{C})$, nitrogen $(\mathrm{N})$, and phosphorus $(\mathrm{P})$ vary with interactions among external inputs and exports, circulation, sedimentwater exchanges, and biological processes. Eutrophication disturbs these integrated processes as allochthonous and autochthonous organic carbon inputs increase in excess of balanced consumption (Nixon, 1995). This imbalance is often stimulated by loading of dissolved inorganic nutrients from the watershed (Cloern, 2001). While this model of coastal fertilization is generally applicable, estuaries have differential capacities to accommodate introduced nutrients through a variety of factors including latitude, geomorphology, and flushing time (Dettmann, 2001; Smith et al., 2003). In particular, sub-tropical estuaries such as those in south Florida have experienced alterations including manipulation of freshwater inflows to meet municipal, agricultural, and environmental demands. Discharge to these estuaries introduces pulses of watershed materials that vary on synoptic to inter-annual timescales depending upon weather, climate, and watershed management (Childers et al., 2006; Dennison, 2008; SFWMD, 2012a, b). 


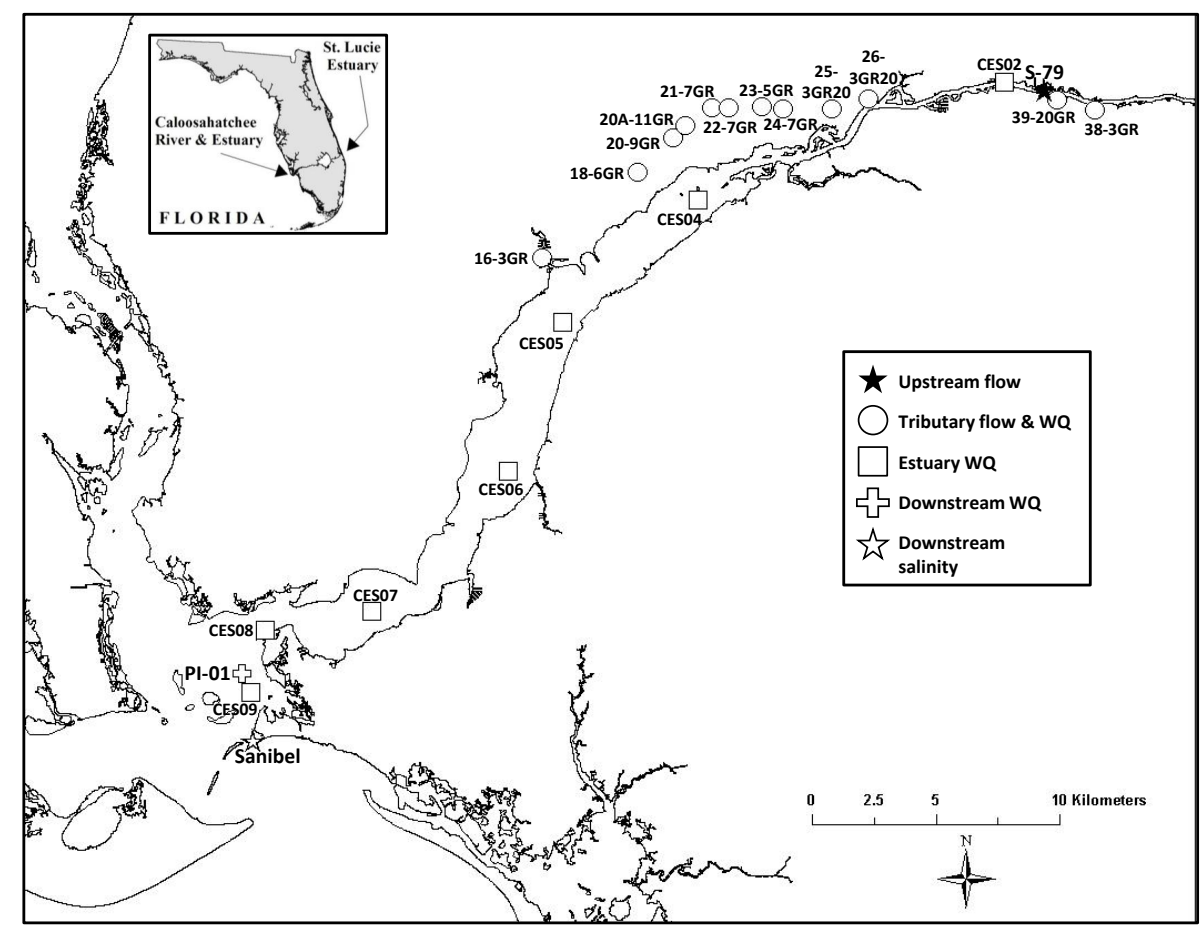

Fig. 1. Map depicting the Caloosahatchee River estuary. See Table 1 and Sect. 2.2 for details of data sources and integration into the nutrient budgets. Included is the upstream boundary site of gauged freshwater inflow (S-79; filled star), 12 locations of tributary water quality data (open circles), 7 locations of estuary water quality data (open squares), the location of downstream water quality data (PI-01; open cross), and the downstream boundary location for salinity (Sanibel; open star).

Baseline quantification of material inputs, flushing time, downstream export, and the potential for internal production or consumption of $\mathrm{C}, \mathrm{N}$, and $\mathrm{P}(\mathrm{CNP})$ is essential to better understand estuarine system metabolism (Gordon et al., 1996; Smith et la., 2005; Giordani et al., 2008). This is particularly true for coastal water bodies with heavily managed freshwater inflow subject to both short- and long-term fluctuations in discharge (Brock, 2001). In fact, sensitivity to both reduced inflows (loss of freshwater and estuarine habitats) and increased inorganic nutrient loading (symptoms of eutrophication) offers an apparent contradiction for estuarine management (Flemer and Champ, 2006). The amount of water and dissolved materials required to maintain optimal system metabolism with regard to CNP production and consumption should be quantified and factored into management plans for coastal watersheds.

In 1993 the International Geosphere-Biosphere Program (IGBP) and the International Human Dimensions Program on Global Environmental Change (IHDP; http://www.loicz. org/; http://nest.su.se/mnode/) initiated a project to investigate biogeochemistry of the coastal zone (Gordon et al., 1996; Smith et al., 2005; Swaney et al., 2011). The LandOcean Interactions in the Coastal Zone (LOICZ) included a spreadsheet tool designed to quantify internal $\mathrm{C}, \mathrm{N}$, and $\mathrm{P}$ sources and sinks in estuaries (Giordani et al., 2008). LOICZ also has been useful in socio-economic-political assessments of human dimensions in the coastal zone (Talaue-McManus et al., 2003; Swaney et al., 2011). The approach has been used to investigate CNP cycling in hundreds of coastal environments (Smith et al., 2005; Giordani et al., 2008; Yamamoto et al., 2008; Liu et al., 2009; Swaney et al., 2011. The spreadsheets are customizable depending upon the quality and quantity of data and can be applied to any estuary without the need for detailed rate process information.

In order to explore internal biogeochemical mechanisms, the overall goal of this study was to generate wet and dry season DIN (dissolved inorganic nitrogen) and DIP (dissolved inorganic phosphorus) budgets for both the Caloosahatchee River and St. Lucie estuaries (CRE and SLE, respectively) from 2002 to 2008. This time period was derived based on data availability and consideration for the range of climatic conditions. The specific objectives were to estimate DIN and DIP loading via atmospheric, groundwater, and surface inputs; to quantify seasonal changes in estuarine salinity and flushing time; to assess seasonal patterns of estuarine DIN and DIP concentrations; and to explore, compare, and contrast relationships between loading, flushing, concentrations, and ecosystem-scale CNP cycling within and between the CRE and SLE. 


\section{Methods}

\subsection{Study sites}

The CRE is located in southwest Florida and has been altered by human activities starting in the 1880 s when the river was straightened and deepened (Fig. 1; Antonini et al., 2002). The first water control structures at Lake Okeechobee (S-77) and Ortona (S-78) were completed in the 1930s with the last installed in 1966 at Olga (S-79; Antonini et al., 2002). The Franklin Lock at S-79 represents the head of the CRE that extends $\sim 42 \mathrm{~km}$ downstream to Shell Point where it empties into the Gulf of Mexico. The meso- and poly-haline estuary downstream of S-79 has also experienced anthropogenic impacts (Chamberlain and Doering, 1998). Early descriptions of the CRE characterize it as barely navigable due to extensive shoals and oyster bars near the estuary's mouth (Sackett, 1888). A navigation channel was dredged with a causeway built across the mouth of San Carlos Bay in the 1960s. Historic oyster bars immediately upstream were mined for road construction.

Located in southeast Florida, the SLE comprises a major tributary to the ecologically and commercially valuable Indian River lagoon (Sime, 2005; Ji et al., 2007; Fig. 2). Historically, the SLE was a freshwater system that was temporarily exposed to the coastal ocean only through ephemeral inlets (United States Army, 1915). The St. Lucie Inlet was permanently opened in 1892 to provide a connection between the SLE and coastal ocean resulting in a partially mixed estuary with semi-diurnal tidal amplitude of $\sim 0.4 \mathrm{~m}$. The past several decades have seen the SLE watershed altered from a system of natural sloughs and wetlands into a series of sub-basins affected by agriculture and urbanization. The SLE has a large watershed: estuary surface area ratio of $150: 1$ (Tampa Bay, $5.5: 1$ ). Watershed changes and periodic highvolume water releases from Lake Okeechobee have altered historical wet season and dry season patterns of nutrient loading. These changes in flow, salinity, and water quality are associated with increased prevalence of phytoplankton blooms, accumulation of muck-like sediments, and the loss of seagrass and oyster habitats (Sime, 2005; SFWMD, 2012a).

\subsection{Application of the LOICZ approach to the Caloosahatchee and St. Lucie estuaries}

Application of the LOICZ approach results in water, salt, DIN, and DIP budgets for the estuary of interest (Gordon et al., 1996; Smith et al., 2005; Giordani et al., 2008; Swaney et al., 2011; the reader is encouraged to refer to these published efforts for conceptual and mathematical details of the LOICZ approach). It was designed to isolate internal, nonconservative production or consumption of dissolved CNP from conservative exchanges for a spatially homogeneous layer, segment, or estuarine water body.

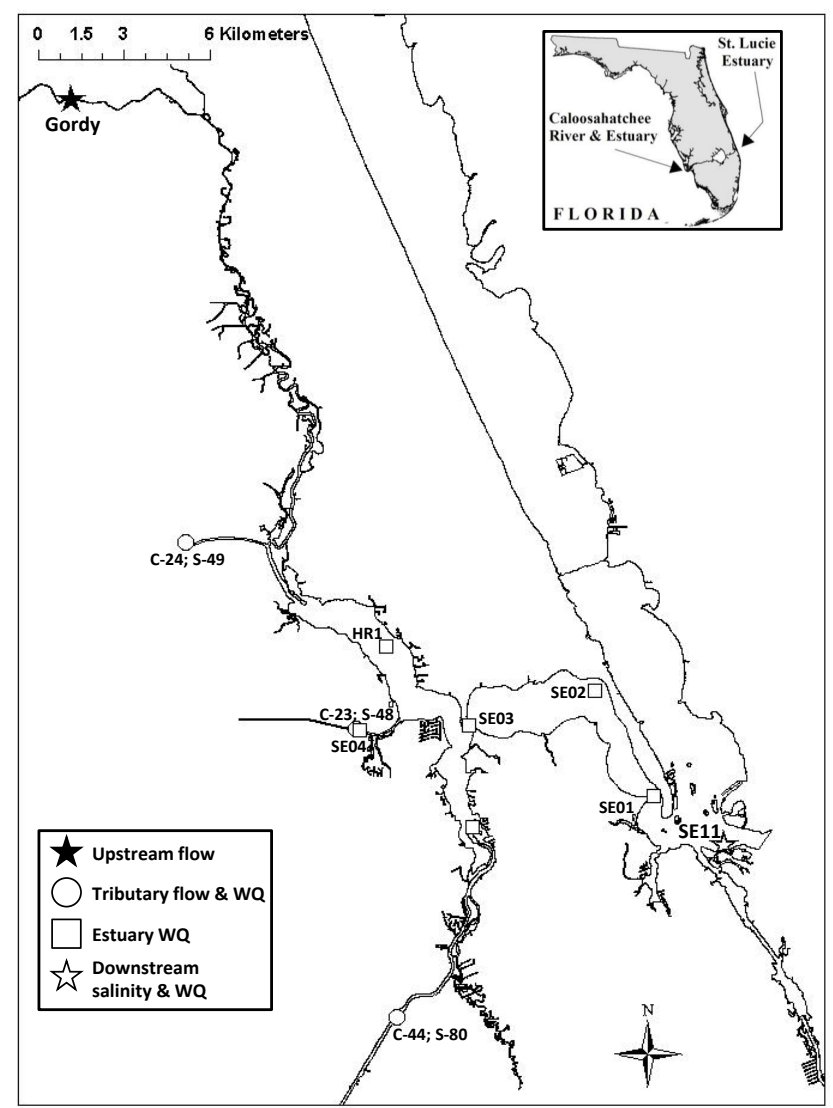

Fig. 2. Map depicting the St. Lucie Estuary. See Table 1 and Sect. 2.2 for details of data sources and integration into the nutrient budgets. Included is the upstream boundary for freshwater inflow (Gordy Rd.; filled star), three locations of tributary water quality and inflow data (open circles), six locations of estuary water quality data (open squares), and the downstream boundary location for water quality and salinity (SE-11; open star).

The approach assumes a steady state condition that balances the sum of physical inputs against the sum of physical outputs (Wosten et al., 2003; Swaney et al., 2011). In general, salinity $(S)$ differences between the estuary and the downstream oceanic boundary are used to define net flows, residual exchange, and flushing time $\left(T_{\mathrm{f}}\right)$. The water budget and hydrodynamic exchange attributes are used to predict internal production or consumption of dissolved inorganic C, $\mathrm{N}$, and $\mathrm{P}$. This study generated budgets in order to evaluate net internal production or consumption of DIN ( $\triangle$ DIN;g $\left.\mathrm{N} \mathrm{m}^{-2} \mathrm{~d}^{-1}\right)$ and DIP ( $\Delta$ DIP; $\left.\mathrm{g} \mathrm{P} \mathrm{m}^{-2} \mathrm{~d}^{-1}\right)$ at the seasonal scale (dry vs. wet seasons). Dry and wet seasons for south Florida were defined using the months of December-May and June-November, respectively. Negative and positive values denote net internal consumption or production, respectively, by the estuarine system. LOICZ relies upon the molar stoichiometry of the photosynthesis-respiration equation to link C, N, and P cycles (Gordon et al., 1996; Smith et al., 2005; Swaney et al., 2011). 
Table 1. Sources of input data for seasonal DIN and DIP budgets for CRE and SLE. Please see Sect. 2.2 for explanation and details and Figs. 1 and 2 for water quantity and quality monitoring locations.

\begin{tabular}{lllll}
\hline Abbreviation & Definition & Unit & CRE & SLE \\
\hline$V_{\text {rain }}$ & Rain to estuary surface & $10^{6} \mathrm{~m}^{3} \mathrm{~d}^{-1}$ & Nexrad & Nexrad \\
$V_{\mathrm{Q}}$ & Freshwater discharge & $10^{6} \mathrm{~m}^{3} \mathrm{~d}^{-1}$ & DBHydro S-79 & DBHydro S484980+ Gordy \\
$V_{\mathrm{OFW}}$ & Tributaries + groundwater & $10^{6} \mathrm{~m}^{3} \mathrm{~d}^{-1}$ & Tidal basin model & 30\% of total Q \\
$V_{\mathrm{e}}$ & Estuary volume & $10^{6} \mathrm{~m}^{3}$ & Interpolated bathymetry & Interpolated bathymetry \\
$S_{\mathrm{e}}$ & Estuary salinity & & DBHydro CES stations & DBHydro SE stations \\
$S_{\mathrm{O}}$ & Downstream bound salinity & & Shell Point daily model & DBHydro station SE-11 \\
DIP $_{\text {rain }}$ & DIP in rain & $\mathrm{g} \mathrm{m}^{-3}$ & DBHydro averages & DBHydro averages \\
DIP $_{\mathrm{Qc}}$ & DIP in discharge & $\mathrm{g} \mathrm{m}^{-3}$ & Lee County Stations & DBHydro S-484980 \\
DIP $_{\mathrm{OFW}}$ & DIP in tributaries $+\mathrm{gw}$ & $\mathrm{g} \mathrm{m}^{-3}$ & Lee County Stations & DBHydro S-484980 \\
DIP $_{\mathrm{e}}$ & DIP in estuary & $\mathrm{g} \mathrm{m}^{-3}$ & DBHydro CES stations & DBHydro SE stations \\
DIP $_{\mathrm{O}}$ & DIP in downstream bound & $\mathrm{g} \mathrm{m}^{-3}$ & Lee County Stn. PI-01 & DBHydro station SE-11 \\
DIN $_{\text {rain }}$ & DIN in rain & $\mathrm{g} \mathrm{m}^{-3}$ & NADP St. Petersburg, FL & NADP St. Petersburg, FL \\
DIN $_{\mathrm{Qc}}$ & DIN in discharge & $\mathrm{g} \mathrm{m}^{-3}$ & DBHydro station S-79 & DBHydro S-484980 \\
DIN $_{\text {OFW }}$ & DIN in tributaries + gw & $\mathrm{g} \mathrm{m}^{-3}$ & Lee County Stations & DBHydro S-484980 \\
DIN $_{\mathrm{e}}$ & DIN in estuary & $\mathrm{g} \mathrm{m}^{-3}$ & DBHydro CES stations & DBHydro SE stations \\
DIN $_{\mathrm{O}}$ & DIN in downstream bound & $\mathrm{g} \mathrm{m}^{-3}$ & Lee County Stn. PI-01 & DBHydro station SE-11 \\
\hline
\end{tabular}

The budgets required DIN and DIP concentrations in rain $\left(\mathrm{DIN}_{\text {rain }}\right.$ and $\left.\mathrm{DIP}_{\text {rain }}\right)$, surface discharge $\left(\mathrm{DIN}_{\mathrm{Qc}}\right.$ and $\left.\mathrm{DIP}_{\mathrm{Qc}}\right)$, other freshwater sources (DIN $\left.\mathrm{OFW}_{\text {and }} \mathrm{DIN}_{\mathrm{OFW}}\right)$, the estuary $\left(\mathrm{DIN}_{\mathrm{e}}\right.$ and $\left.\mathrm{DIP}_{\mathrm{e}}\right)$, and the oceanic boundary $\left(\mathrm{DIN}_{\mathrm{o}}\right.$ and $\mathrm{DIP}_{\mathrm{o}}$ ). Seasonal hydrological inputs via the atmosphere, groundwater, and surface inflow; salinity; and DIN and DIP concentrations in the upstream, tributaries and ground water, main water body; and downstream oceanic boundary from 2002 to 2008 were assembled for each estuary (Table 1).

Since DIP does not have an air-sea conversion term it is assumed to be in stoichiometric balance with dissolved inorganic carbon (DIC) mass in the estuarine volume. Using straightforward Redfield stoichiometry (mo$\operatorname{lar} \mathrm{C}: \mathrm{N}: \mathrm{P}=106: 16: 1), \Delta \mathrm{DIP}$ can be converted to net ecosystem metabolism (NEM; $\mathrm{g} \mathrm{C} \mathrm{m}^{-2} \mathrm{~d}^{-1}$ ) with NEM defined as a positive number (autotrophic) when the system consumes DIP internally (Yamamoto et al., 2008). In contrast, there is net exchange of DIN between the water and atmosphere through microbially mediated $\mathrm{N}$ cycling that confounds direct inter-conversion through stoichiometry. The LOICZ budgets are used to calculate the actual $\triangle D I N$ from differences in DIN imports and exports, and, the expected $\Delta \mathrm{DIN}\left(\Delta \mathrm{DIN}_{\mathrm{exp}}\right)$ from $\Delta$ DIP and the $\mathrm{N}: \mathrm{P}$ ratio of particulate matter $\left(\mathrm{N}: \mathrm{P}_{\text {part }}=16\right)$. The difference between the two values represents the relative difference between $\mathrm{N}_{2}$ fixation and denitrification $\left(\mathrm{N}_{\mathrm{fix}} D>0.0=\right.$ net $\mathrm{N}_{2}$ fixation; Yamamoto et al., 2008; Swaney et al., 2011).

Each estuarine water body was bounded and assumed to represent a homogenous volume to assess system-level internal cycling of CNP. While splitting each estuary spatially into multiple segments and vertically into multiple layers can be desirable (Webster et al., 2000), treating each estuary as a sin- gle box was optimal for initial assessments. The CRE was assumed to extend from the Franklin Lock (S-79) to Shell Point (CES09) approximately $40 \mathrm{~km}$ downstream (Fig. 1). Estuarine surface area for the CRE is $56.9 \mathrm{~km}^{2}\left(56900000 \mathrm{~m}^{2}\right)$ with an average depth of $2.4 \mathrm{~m}$ (Buzzelli et al, 2013b). In contrast, the SLE has multiple upstream points of freshwater inflow (Fig. 2). Three water control structures (S-49, S-48, S-80) provided upstream boundaries for the SLE. The final upstream bound was the St. Lucie Blvd. Bridge in the North Fork, which was assumed to possess flow indicative of a gated structure located farther upstream (Gordy Rd.; Fig. 2). The downstream boundary was the St. Lucie Inlet. Estuarine surface area for the SLE is $22.0 \mathrm{~km}^{2}\left(22000000 \mathrm{~m}^{2}\right)$ with an average depth of $2.7 \mathrm{~m}$ (Buzzelli et al., 2013b).

Average monthly rainfall $\left(\mathrm{m}^{3} \mathrm{~d}^{-1}\right)$ directly to the water surfaces of the CRE and SLE was queried from NEXRAD data available through the South Florida Water Management District (SFWMD) publicly accessible database (DBHydro; http://www.sfwmd.gov/dbhydroplsql/ show_dbkey_info.main_menu). Seasonal rainfall amounts for the CRE and SLE were summed from the time series of monthly averages. Daily freshwater inflow rate to the CRE at S-79 $\left(\mathrm{m}^{3} \mathrm{~d}^{-1}\right)$ available through DBHydro was averaged over each dry and wet season. Other freshwater inflow $\left(\mathrm{m}^{3} \mathrm{~d}^{-1}\right)$ representative of combined tributary and ground water input to the CRE was derived using a tidal basin watershed model presently in development at the SFWMD (Y. Wan, unpublished data; Table 2).

Total daily freshwater discharge to the SLE from DBHydro was estimated by summing daily inflow measurements at structures S-48, S-49, S-80, and Gordy Rd and then averaged over each season. By contrast, the sum of freshwater inflow 
Table 2. Inputs for seasonal DIN and DIP budgets for the CRE. Values are seasonal averages from 2002 to 2008 for water, salt, DIN, and DIP budgets. The wet season consisted of months 6-11 (June-November) within each year. The dry season consisted of month 12 (December) from the preceding year followed by the first 5 months (January-May) of the next year. Abbreviations and units shown for average daily input of rain $\left(V_{\text {rain }} ; 10^{6} \mathrm{~m}^{3} \mathrm{~d}^{-1}\right)$, upstream flow or discharge $\left(V_{\mathrm{Q}} ; 10^{6} \mathrm{~m}^{3} \mathrm{~d}^{-1}\right)$, and other freshwater sources $\left(V_{\mathrm{OFW}} ; 10^{6} \mathrm{~m}^{3} \mathrm{~d}^{-1}\right)$; salinity in the estuary $\left(S_{\mathrm{e}}\right)$ and downstream or ocean boundary $\left(S_{\mathrm{O}}\right)$; and concentrations of DIN and DIP in rainfall (DIN rain $_{\text {and DIP }}$ rain), discharge $\left(\mathrm{DIN}_{\mathrm{Qc}_{\mathrm{c}}}\right.$ and $\left.\mathrm{DIP}_{\mathrm{Qc}_{\mathrm{c}}}\right)$, the estuary (DIN $\mathrm{e}_{\mathrm{e}}$ and DIPe $)$, and the ocean boundary $\left(\mathrm{DIN}_{\mathrm{o}}\right.$ and $\left.\mathrm{DIP}_{\mathrm{o}}\right)$. All concentrations are in $\mathrm{g} \mathrm{m}^{-3}$. DIN and DIP in other freshwater sources (DIN $\mathrm{OFW}_{\text {and }}$ DIP $\mathrm{OFW}_{\text {) }}$ ) were assumed to be equal to $\mathrm{DIN}_{\mathrm{Qc}}$ and $\mathrm{DIP}_{\mathrm{Qc}}$. See text for specifics and sources of input data for budget development. CRE volume was assumed to be constant $\left(V_{\mathrm{CRE}}=140 \times 10^{6} \mathrm{~m}^{3}\right)$.

\begin{tabular}{|c|c|c|c|c|c|c|c|c|c|c|c|c|c|c|}
\hline \multirow[b]{2}{*}{ year } & \multirow[b]{2}{*}{ season } & \multicolumn{3}{|c|}{ Water } & \multicolumn{2}{|c|}{ Salt } & \multicolumn{4}{|c|}{ DIP } & \multicolumn{4}{|c|}{ DIN } \\
\hline & & $V_{\text {rain }}$ & $V_{\mathrm{Q}}$ & $V_{\mathrm{OFW}}$ & $S_{\mathrm{e}}$ & $S_{\mathrm{o}}$ & $\mathrm{DIP}_{\text {rain }}$ & $\mathrm{DIP}_{\mathrm{Qc}}$ & $\mathrm{DIP}_{\mathrm{e}}$ & $\mathrm{DIP}_{\mathrm{o}}$ & $\mathrm{DIN}_{\text {rain }}$ & $\mathrm{DIN}_{\mathrm{Qc}}$ & $\mathrm{DIN}_{\mathrm{e}}$ & $\mathrm{DIN}_{\mathrm{O}}$ \\
\hline \multirow[t]{2}{*}{2002} & Dry & 0.1 & 2.2 & 0.4 & 12.6 & 30.2 & 0.04 & 0.16 & 0.06 & 0.05 & 0.75 & 0.27 & 0.10 & 0.04 \\
\hline & Wet & 0.5 & 8.1 & 0.9 & 7.9 & 18.8 & 0.08 & 0.09 & 0.11 & 0.07 & 0.96 & 0.15 & 0.16 & 0.15 \\
\hline \multirow[t]{2}{*}{2003} & Dry & 0.1 & 4.6 & 0.5 & 8.4 & 21.7 & 0.04 & 0.05 & 0.05 & 0.02 & 0.82 & 0.15 & 0.11 & 0.04 \\
\hline & Wet & 0.4 & 15.4 & 2.7 & 8.2 & 12.5 & 0.08 & 0.08 & 0.06 & 0.04 & 0.78 & 0.14 & 0.23 & 0.11 \\
\hline \multirow[t]{2}{*}{2004} & Dry & 0.1 & 4.5 & 0.4 & 10.6 & 24.1 & 0.04 & 0.04 & 0.04 & 0.02 & 0.45 & 0.12 & 0.12 & 0.06 \\
\hline & Wet & 0.4 & 13.3 & 9.3 & 6.5 & 17.1 & 0.08 & 0.06 & 0.07 & 0.03 & 0.73 & 0.14 & 0.18 & 0.13 \\
\hline \multirow[t]{2}{*}{2005} & Dry & 0.2 & 7.2 & 0.5 & 6.2 & 20.8 & 0.04 & 0.03 & 0.05 & 0.02 & 0.74 & 0.13 & 0.35 & 0.12 \\
\hline & Wet & 0.5 & 19.6 & 2.2 & 1.6 & 9.5 & 0.08 & 0.05 & 0.08 & 0.06 & 0.58 & 0.12 & 0.30 & 0.19 \\
\hline \multirow[t]{2}{*}{2006} & Dry & 0.1 & 2.2 & 0.4 & 1.9 & 22.6 & 0.04 & 0.03 & 0.05 & 0.02 & 1.19 & 0.15 & 0.25 & 0.12 \\
\hline & Wet & 0.4 & 4.2 & 1.9 & 7.4 & 23.1 & 0.08 & 0.07 & 0.11 & 0.06 & 0.68 & 0.14 & 0.20 & 0.09 \\
\hline \multirow[t]{2}{*}{2007} & Dry & 0.1 & 0.2 & 0.3 & 19.4 & 33.1 & 0.04 & 0.07 & 0.06 & 0.02 & 1.22 & 0.12 & 0.16 & 0.04 \\
\hline & Wet & 0.3 & 0.4 & 0.8 & 15.7 & 31.2 & 0.08 & 0.08 & 0.11 & 0.01 & 0.84 & 0.17 & 0.10 & 0.07 \\
\hline \multirow[t]{2}{*}{2008} & Dry & 0.1 & 0.4 & 0.4 & 20.0 & 34.0 & 0.04 & 0.07 & 0.05 & 0.01 & 0.77 & 0.18 & 0.08 & 0.03 \\
\hline & Wet & 0.5 & 6.1 & 2.5 & 9.1 & 22.1 & 0.08 & 0.08 & 0.11 & 0.04 & 0.77 & 0.19 & 0.13 & 0.05 \\
\hline
\end{tabular}

from four gauged input canals (C-44, C-23, C-24, and North Fork) is approximately $70 \%$ of the total freshwater input to the SLE (Ji et al., 2007). Thus, other freshwater input to the SLE was added as $30 \%$ of the total summed daily discharge of surface water (Table 3 ).

$\mathrm{S}$ in the CRE was based on an average of seven midchannel stations (CES02, CES04, CES05, CES06, CES07, CES08, CES09; Fig. 1; Table 2). Similarly, average seasonal $\mathrm{S}$ in the SLE was calculated using monitoring data from five stations (SE01, SE02, SE03, SE04, HR1; Fig. 2; Table 3). Daily $\mathrm{S}$ predicted at the Sanibel Bridge using a 3-D hydrodynamic model provided the downstream boundary for the CRE water budgets (Fig. 1; D. Sun and Y. Wan, unpublished data; Table 2). S values at the oceanic boundary of the SLE were from observational data at the most downstream station (SE-11; Fig. 2; Table 3).

Seasonally varying concentrations of DIP in rain (DIP rain $; \mathrm{g} \mathrm{P} \mathrm{m}^{-3}$ ) from 2002 to 2008 were from data available in DBHydro (Table 2). Seasonally varying concentrations of DIN in rain $\left(\mathrm{DIN}_{\text {rain }} ; \mathrm{g} \mathrm{N} \mathrm{m}^{-3}\right)$ was calculated by summing $\mathrm{NO}_{2}^{-}+\mathrm{NO}_{3}^{-}+\mathrm{NH}_{4}^{+}$concentrations from St. Petersburg, FL, as part of the National Atmospheric Deposition Program (NADP; http://nadp.sws.uiuc.edu/data/ ntndata.aspx). Atmospheric concentrations were assumed to be representative of the south Florida region so the same seasonal time series of $\mathrm{DIP}_{\text {rain }}$ and $\mathrm{DIN}_{\text {rain }}$ were applied to both estuaries. Lee County in southwest Florida maintains a water quality database for the CRE and its tributaries (available at http://www.lee-county.com/gov/dept/ naturalresources/WaterQuality/Pages/default.aspx). DIN and DIP concentrations $\left(\mathrm{g} \mathrm{N} \mathrm{m}^{-3} ; \mathrm{g} \mathrm{P} \mathrm{m}^{-3}\right)$ from 12 tributary stations were averaged by season for use as DIP ${ }_{\mathrm{OFW}}$ and

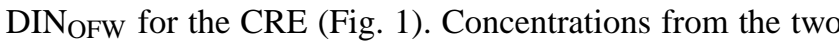
upstream stations (38-3GR and 39-20GR) were used for $\mathrm{DIP}_{\mathrm{Qc}}$ and $\mathrm{DIN}_{\mathrm{Qc}}$ in order to calculate DIP and DIN loading at S-79 (DIP ${ }_{\mathrm{Q}}$ and $\mathrm{DIN}_{\mathrm{Q}} ; \mathrm{g} \mathrm{d}^{-1}$; Table 2$)$. The concentrations of DIP (DIP $\left.; \mathrm{g} \mathrm{P} \mathrm{m}^{-3}\right)$ and DIN $\left(\mathrm{DIN}_{\mathrm{e}} ; \mathrm{g} \mathrm{N} \mathrm{m}^{-3}\right)$ in the main body of the CRE were derived from monthly monitoring at the seven mid-estuary stations (CES02-CES09). Finally, data from the Lee County station PI-01 were the source of DIP and DIN concentrations at the oceanic boundary of the CRE (DIP ${ }_{\mathrm{o}}$ and $\mathrm{DIN}_{\mathrm{o}}$; Table 2).

Seasonally averaged concentrations of DIP $\left(\mathrm{g} \mathrm{P} \mathrm{m}^{-3}\right)$ and DIN $\left(\mathrm{g} \mathrm{N} \mathrm{m}^{-3}\right.$ ) observed at S-49, S-48, and $\mathrm{S}-80$ provided $\mathrm{DIP}_{\mathrm{Qc}_{\mathrm{c}}}$ and $\mathrm{DIN}_{\mathrm{Qc}}$ to estimate surface loadings to the SLE (DIP ${ }_{\mathrm{Q}}$ and $\mathrm{DIN}_{\mathrm{Q}} ; \mathrm{g} \mathrm{d}^{-1}$; Table 3 ). DIP $\mathrm{OFW}$ and DIN $\mathrm{OFW}_{\text {con- }}$ centrations were assumed to be equal to $\mathrm{DIP}_{\mathrm{Qc}}$ and $\mathrm{DIN}_{\mathrm{Qc}}$. DIP (DIP $; \mathrm{g} \mathrm{P} \mathrm{m}^{-3}$ ) and DIN (DIN ${ }_{\mathrm{e}} ; \mathrm{g} \mathrm{N} \mathrm{m}^{-3}$ ) concentrations in the main body of the SLE were derived from monthly monitoring at the five mid-estuary stations (Fig. 2; Table 3). Nutrient concentrations observed at SE11 provided the condition at the oceanic boundary ( $\mathrm{DIP}_{\mathrm{o}}$ and $\left.\mathrm{DIN}_{\mathrm{o}} ; \mathrm{g} \mathrm{m}^{-3}\right)$.

LOICZ water, salt, and nutrient budgets were generated using MS Excel spreadsheets and macros for two different time periods (dry vs. wet seasons). Annual spreadsheets were created for each of the $7 \mathrm{yr}$ (2002-2008) for both the CRE 
Table 3. Inputs for seasonal DIN and DIP budgets for the SLE. Values are seasonal averages from 2002 to 2008 for water, salt, DIN, and DIP budgets. The wet season consisted of months 6-11 (June-November) within each year. The dry season consisted of month 12 (December) from the preceding year followed by the first 5 months (January-May) of the next year. Abbreviations and units shown for average daily input of rain $\left(V_{\text {rain }} ; 10^{6} \mathrm{~m}^{3} \mathrm{~d}^{-1}\right)$, upstream flow or discharge $\left(V_{\mathrm{Q}} ; 10^{6} \mathrm{~m}^{3} \mathrm{~d}^{-1}\right)$, and other freshwater sources $\left(V_{\mathrm{OFW}} ; 10^{6} \mathrm{~m}^{3} \mathrm{~d}^{-1}\right) ;$ salinity in the estuary $\left(S_{\mathrm{e}}\right)$ and downstream or ocean boundary $\left(S_{\mathrm{o}}\right)$; and concentrations of DIN and DIP in rainfall (DIN rain $_{\text {and DIP }}$ rain), discharge $\left(\mathrm{DIN}_{\mathrm{Qc}}\right.$ and $\left.\mathrm{DIP}_{\mathrm{Qc}_{\mathrm{c}}}\right)$, the estuary $\left(\mathrm{DIN}_{\mathrm{e}}\right.$ and $\left.\mathrm{DIP}_{\mathrm{e}}\right)$, and the ocean boundary $\left(\mathrm{DIN}_{\mathrm{o}}\right.$ and $\left.\mathrm{DIP}_{\mathrm{o}}\right)$. All concentrations are in $\mathrm{g} \mathrm{m}^{-3}$. DIN and DIP in other freshwater sources (DIN $\mathrm{OFW}_{\mathrm{W}}$ and $\mathrm{DIP}_{\mathrm{OFW}}$ ) were assumed to be equal to $\mathrm{DIN}_{\mathrm{Qc}}$ and $\mathrm{DIP}_{\mathrm{Qc}}$. See text for specifics and sources of input data for budget development. SLE volume was assumed to be constant $\left(V_{\mathrm{SLE}}=53 \times 10^{6} \mathrm{~m}^{3}\right)$.

\begin{tabular}{|c|c|c|c|c|c|c|c|c|c|c|c|c|c|c|}
\hline \multirow[b]{2}{*}{ year } & \multirow[b]{2}{*}{ season } & \multicolumn{3}{|c|}{ Water } & \multicolumn{2}{|c|}{ Salt } & \multicolumn{4}{|c|}{ DIP } & \multicolumn{4}{|c|}{ DIN } \\
\hline & & $V_{\text {rain }}$ & $V_{\mathrm{Q}}$ & $V_{\mathrm{OFW}}$ & $S_{\mathrm{e}}$ & $S_{\mathrm{o}}$ & $\mathrm{DIP}_{\text {rain }}$ & $\mathrm{DIP}_{\mathrm{Qc}}$ & $\mathrm{DIP}_{\mathrm{e}}$ & $\mathrm{DIP}_{\mathrm{o}}$ & $\mathrm{DIN}_{\text {rain }}$ & $\mathrm{DIN}_{\mathrm{Qc}}$ & $\mathrm{DIN}_{\mathrm{e}}$ & $\mathrm{DIN}_{\mathrm{O}}$ \\
\hline \multirow[t]{2}{*}{2002} & Dry & 0.03 & 0.5 & 0.2 & 20.3 & 33.2 & 0.04 & 0.10 & 0.08 & 0.02 & 0.75 & 0.16 & 0.09 & 0.06 \\
\hline & Wet & 0.06 & 3.7 & 1.1 & 14.2 & 26.7 & 0.08 & 0.12 & 0.18 & 0.09 & 0.96 & 0.19 & 0.19 & 0.15 \\
\hline \multirow[t]{2}{*}{2003} & Dry & 0.04 & 2.9 & 0.9 & 17.7 & 30.6 & 0.04 & 0.16 & 0.08 & 0.02 & 0.82 & 0.19 & 0.11 & 0.05 \\
\hline & Wet & 0.07 & 6.2 & 1.9 & 5.9 & 18.0 & 0.08 & 0.09 & 0.18 & 0.09 & 0.78 & 0.23 & 0.18 & 0.17 \\
\hline \multirow[t]{2}{*}{2004} & Dry & 0.03 & 2.0 & 0.6 & 17.2 & 30.4 & 0.04 & 0.09 & 0.06 & 0.02 & 0.45 & 0.20 & 0.07 & 0.04 \\
\hline & Wet & 0.90 & 7.8 & 2.4 & 11.2 & 25.9 & 0.08 & 0.29 & 0.21 & 0.1 & 0.73 & 0.34 & 0.36 & 0.24 \\
\hline \multirow[t]{2}{*}{2005} & Dry & 0.05 & 2.8 & 0.8 & 13.8 & 28.5 & 0.04 & 0.38 & 0.06 & 0.02 & 0.74 & 0.39 & 0.19 & 0.04 \\
\hline & Wet & 0.10 & 9.9 & 3.0 & 2.3 & 17.4 & 0.08 & 0.70 & 0.20 & 0.14 & 0.58 & 0.21 & 0.26 & 0.21 \\
\hline \multirow[t]{2}{*}{2006} & Dry & 0.02 & 2.2 & 0.7 & 14.1 & 30.8 & 0.04 & 0.41 & 0.07 & 0.03 & 1.19 & 0.33 & 0.20 & 0.05 \\
\hline & Wet & 0.05 & 1.0 & 0.3 & 19.5 & 31.9 & 0.08 & 0.41 & 0.18 & 0.04 & 0.68 & 0.70 & 0.18 & 0.04 \\
\hline \multirow[t]{2}{*}{2007} & Dry & 0.02 & 0.2 & 0.1 & 27.7 & 35.9 & 0.04 & 0.17 & 0.07 & 0.01 & 1.22 & 0.19 & 0.02 & 0.02 \\
\hline & Wet & 0.10 & 1.7 & 0.5 & 16.2 & 33.3 & 0.08 & 0.68 & 0.17 & 0.02 & 0.84 & 0.25 & 0.16 & 0.03 \\
\hline \multirow[t]{2}{*}{2008} & Dry & 0.04 & 0.4 & 0.1 & 20.2 & 34.0 & 0.04 & 0.23 & 0.07 & 0.01 & 0.77 & 0.18 & 0.06 & 0.02 \\
\hline & Wet & 0.10 & 2.7 & 0.8 & 9.4 & 24.8 & 0.08 & 0.87 & 0.12 & 0.05 & 0.77 & 0.19 & 0.17 & 0.11 \\
\hline
\end{tabular}

and SLE (14 total spreadsheets). Each annual spreadsheet had input and result pages for both the dry and wet seasons with each result page including both DIN and DIP budget values. Data assembly and entry for budget calculations was the most time intensive and important part of budget development (Tables 2, 3). Results from the LOICZ budgets were collated within each estuary with results for the CRE and SLE combined for graphical and tabular presentation.

\section{Results}

\subsection{Caloosahatchee River estuary}

Rainfall directly to the surface of the CRE ranged $0.1-$ $0.15 \times 10^{6} \mathrm{~m}^{3} \mathrm{~d}^{-1}$ and $0.35-0.45 \times 10^{6} \mathrm{~m}^{3} \mathrm{~d}^{-1}$ in the dry and wet seasons, respectively (Fig. 3a). Total rainfall varied inter-annually for both the dry and wet seasons of 20022008. Freshwater discharge to the CRE revealed long-term variability with maximum values of $15-20 \times 10^{6} \mathrm{~m}^{3} \mathrm{~d}^{-1}$ in the wet seasons of 2003-2005 followed by minimal inflow for both seasons beginning in 2006 (Fig. 3b). Freshwater input from the tidal basin downstream of S-79 generally reflected patterns of surface flow except for the extreme peak in the wet season of $2005\left(\sim 9 \times 10^{6} \mathrm{~m}^{3} \mathrm{~d}^{-1}\right.$; Fig. 3c).

Salinity in the CRE was inverse to freshwater discharge ranging from 7 to 13 in both wet and dry seasons of 20022004 before values $<2.0$ in the wet season of 2005 and dry season of 2006 (Fig. 4a). The salinity of the CRE de- creased from 20 to $<5$ with increased freshwater inflow over all seasonal water budgets of 2002-2008 (Fig. 5a). Average salinity increased to $\geq 20.0$ in the dry seasons of 2007 and 2008 when discharge was lowest and the $T_{\mathrm{f}}$ of the CRE approached 50 and 70 days, respectively (Fig. 6a). Estuarywide, average DIN concentrations exhibited inter-annual climatic fluctuations similar to patterns of inflow from 2002 to 2008 (Fig. 4b). DIN ranged from 0.1 to $0.25 \mathrm{~g} \mathrm{~m}^{-3}$ from 2002 to 2005 before reaching $0.35 \mathrm{~g} \mathrm{~m}^{-3}$ in 2005 . Average DIN concentrations decreased in both dry and wet seasons of 2006-2008. Over all seasonal budgets, the concentration of DIN in the CRE ranged from 0 to $0.35 \mathrm{~g} \mathrm{~m}^{-3}$ and exhibited a modest increase with external loading of DIN up to $0.06 \mathrm{~g} \mathrm{~N} \mathrm{~m}^{-2} \mathrm{~d}^{-1}$ (Fig. 5b). The relationship between flushing time and DIN concentrations were unclear although DIN was reduced $\left(\sim 0.1 \mathrm{~g} \mathrm{~m}^{-3}\right)$ when $T_{\mathrm{f}}=50 \mathrm{~d}$ (Fig. 6b). In contrast to DIN, DIP concentrations in the CRE were remarkably consistent ranging from 0.03 to 0.12 across all seasons and years (Fig. 4c). In fact, there was no obvious relationship between either the external loading of DIP (0.0$\left.0.025 \mathrm{~g} \mathrm{P} \mathrm{m}^{-2} \mathrm{~d}^{-1}\right)$, or $T_{\mathrm{f}}$ and internal DIP concentrations in the CRE $\left(0.025-0.10 \mathrm{~g} \mathrm{~m}^{-3}\right.$; Figs. 5c, 6c). DIP concentrations declined $\left(<0.075 \mathrm{~g} \mathrm{~m}^{-3}\right)$ when inflow was greatest from 2004 to 2005 (Fig. 5c).

The LOICZ budgets indicated that DIN was produced within the CRE ( $\Delta$ DIN $>0.0$ ) in wet season of 2003 , the wet season of 2004, and both seasons in 2005 (Fig. 7a). Aside from these instances, $\Delta$ DIN was near zero for a 
Table 4. Rates of internal dissolved CNP turnover resulting from seasonal DIN and DIP budgets of CRE and SLE from 2002 to 2008. Net internal production or consumption of DIN and DIP were derived through a budgeting process that incorporates water, salt, and input concentrations ( $\Delta \mathrm{N}, \mathrm{g} \mathrm{N} \mathrm{m}^{-2} \mathrm{~d}^{-1} ; \Delta \mathrm{P}, \mathrm{g} \mathrm{P} \mathrm{m}^{-2} \mathrm{~d}^{-1}$; Swaney et al., 2011). The DIP rate was converted to net ecosystem metabolism (NEM; $\left.\mathrm{g} \mathrm{C} \mathrm{m}^{-2} \mathrm{~d}^{-1}\right)$. Average values were calculated across all dry and all wet seasons, respectively.

\begin{tabular}{|c|c|c|c|c|c|c|c|c|c|}
\hline \multirow[b]{2}{*}{ year } & \multirow[b]{2}{*}{ season } & \multicolumn{4}{|c|}{ CRE } & \multicolumn{4}{|c|}{ SLE } \\
\hline & & $\mathrm{g} \mathrm{N} \mathrm{m}^{-2} \mathrm{~d}^{-1}$ & $\begin{array}{r}\Delta \mathrm{P} \\
\mathrm{g} \mathrm{P} \mathrm{m}^{-2} \mathrm{~d}^{-1}\end{array}$ & $\begin{array}{r}\text { NEM } \\
\mathrm{g} \mathrm{C} \mathrm{m}^{-2} \mathrm{~d}^{-1}\end{array}$ & $\begin{array}{r}N_{\text {fix }} D \\
\mathrm{~g} \mathrm{~N} \mathrm{~m}^{-2} \mathrm{~d}^{-1}\end{array}$ & $\mathrm{~g} \mathrm{~N} \mathrm{~m}^{-2} \mathrm{~d}^{\Delta \mathrm{N}}$ & $\begin{array}{r}\Delta \mathrm{P} \\
\mathrm{g} \mathrm{P} \mathrm{m}^{-2} \mathrm{~d}^{-1}\end{array}$ & $\begin{array}{r}\text { NEM } \\
\mathrm{g} \mathrm{C} \mathrm{m}^{-2} \mathrm{~d}^{-1}\end{array}$ & $\begin{array}{r}\mathrm{N}_{\mathrm{fix}} \mathrm{D} \\
\mathrm{g} \mathrm{N} \mathrm{m}^{-2} \mathrm{~d}^{-1}\end{array}$ \\
\hline \multirow[t]{2}{*}{2002} & Dry & 0.006 & -0.004 & 0.16 & 0.03 & -0.002 & 0.003 & -0.11 & -0.02 \\
\hline & Wet & -0.001 & 0.009 & -0.37 & -0.07 & 0.011 & 0.034 & -1.39 & -0.23 \\
\hline \multirow[t]{2}{*}{2003} & Dry & -0.001 & 0.004 & -0.16 & -0.03 & -0.002 & -0.0005 & 0.02 & 0.002 \\
\hline & Wet & 0.259 & 0.021 & -0.84 & 0.11 & -0.017 & 0.052 & -2.12 & -0.39 \\
\hline \multirow[t]{2}{*}{2004} & Dry & 0.003 & 0.001 & -0.06 & -0.01 & -0.010 & 0.004 & -0.15 & -0.04 \\
\hline & Wet & 0.028 & 0.010 & -0.59 & -0.08 & 0.056 & 0.021 & -0.85 & -0.09 \\
\hline \multirow{2}{*}{2005} & Dry & 0.044 & 0.004 & -0.17 & 0.01 & -0.010 & -0.048 & 1.97 & 0.34 \\
\hline & Wet & 0.078 & 0.010 & -0.58 & -0.02 & 0.027 & -0.287 & 11.8 & 2.10 \\
\hline \multirow[t]{2}{*}{2006} & Dry & 0.004 & 0.001 & -0.05 & -0.005 & -0.001 & -0.068 & 2.79 & 0.49 \\
\hline & Wet & 0.010 & 0.008 & -0.33 & -0.05 & -0.018 & -0.002 & 0.07 & -0.01 \\
\hline \multirow[t]{2}{*}{2007} & Dry & 0.001 & 0.001 & -0.03 & -0.005 & 0.001 & 0.002 & -0.07 & -0.01 \\
\hline & Wet & -0.004 & 0.005 & -0.19 & -0.04 & 0.002 & -0.034 & 1.37 & 0.24 \\
\hline \multirow[t]{2}{*}{2008} & Dry & -0.001 & 0.001 & -0.04 & -0.008 & -0.002 & -0.001 & 0.04 & 0.01 \\
\hline & Wet & -0.002 & 0.015 & -0.40 & -0.11 & 0.0004 & -0.112 & 3.07 & 0.81 \\
\hline \multirow[t]{2}{*}{ Average } & Dry & 0.006 & 0.001 & -0.050 & -0.003 & -0.004 & -0.016 & 0.639 & 0.109 \\
\hline & Wet & 0.052 & 0.012 & -0.471 & -0.036 & 0.009 & -0.047 & 1.703 & 0.347 \\
\hline
\end{tabular}

majority of the 2002-2008 budgets averaging 0.006 and $0.052 \mathrm{~g} \mathrm{~N} \mathrm{~m}^{-2} \mathrm{~d}^{-1}$ for the dry and wet seasons, respectively (Table 4). Internal DIN production did not dramatically increase with the loading of external DIN to the CRE despite a maximum input rate of $0.25 \mathrm{~g} \mathrm{~N} \mathrm{~m}^{-2} \mathrm{~d}^{-1}$ in the wet season of 2003 (Fig. 8a). There was no apparent net DIN production or consumption $\left(\sim 0.0 \mathrm{~g} \mathrm{~N} \mathrm{~m}^{-2} \mathrm{~d}^{-1}\right)$ by the CRE when $T_{\mathrm{f}}$ $\geq 10 \mathrm{~d}$ (Fig. 9a). Similar to $\Delta$ DIN, internal $\Delta$ DIP was positive averaging 0.001 and $0.012 \mathrm{~g} \mathrm{P} \mathrm{m}^{-2} \mathrm{~d}^{-1}$ suggesting that the CRE was heterotrophic ( -0.05 to $-0.47 \mathrm{~g} \mathrm{C} \mathrm{m}^{-2} \mathrm{~d}^{-1}$ ) across all seasonal budgets (Table 4, Fig. 7c). There was no discernible relationship between $\Delta$ DIP and DIP loading or flushing time (Figs. 8b, 9b). NEM of the CRE signified a balance between internal production and consumption of primary production over all seasonal budgets. Moreover, average seasonal $\mathrm{N}_{\mathrm{fix}} \mathrm{D}$ was negative in both the dry $(-0.003 \mathrm{~g}$ $\left.\mathrm{N} \mathrm{m}^{-2} \mathrm{~d}^{-1}\right)$ and wet $\left(-0.036 \mathrm{~g} \mathrm{~N} \mathrm{~m}^{-2} \mathrm{~d}^{-1}\right)$ seasons indicating net denitrification with an order of magnitude more occurring in the wet season (Table 4). $\mathrm{N}_{\mathrm{fix}} D$ did not fluctuate with NEM in the CRE (Fig. 10a).

\subsection{St. Lucie Estuary}

Rainfall directly to the surface of the SLE ranged from 0.05 to $0.9 \times 10^{6} \mathrm{~m}^{3} \mathrm{~d}^{-1}$ across all seasonal budgets (Fig. 3a). Except for the extreme value of $0.9 \times 10^{6} \mathrm{~m}^{3} \mathrm{~d}^{-1}$ in the wet season of 2004, total seasonal rainfall was $\leq 0.1 \times 10^{6} \mathrm{~m}^{3} \mathrm{~d}^{-1}$. Freshwater discharge to the SLE was variable with maximum values of $\sim 10 \times 10^{6} \mathrm{~m}^{3} \mathrm{~d}^{-1}$ in the wet seasons of 20032005 followed by low inflow for both dry and wet seasons beginning in 2006 (Fig. 3b). Surface water inflow was very low from 2007 to 2008. Basin inflow was proportional to surface discharge across all seasons (Fig. 3c).
Salinity in the SLE was inverse to freshwater discharge ranging from 6 to 20 in both wet and dry seasons of 20022004 after which values decreased to $<2.0$ in the wet season of 2005 (Fig. 4a). The salinity of the SLE decreased from 27.0 to $<2.0$ with increased freshwater inflow across all water budgets from 2002 to 2008 (Fig. 5a). Average salinity increased to 27.0 in the dry season of 2007 when discharge was least and $T_{\mathrm{f}}=40$ days (Fig. 6a). Estuary-wide, average DIN concentrations exhibited inter-annual fluctuations similar to patterns of inflow from 2002 to 2008 (Fig. 4b). DIN ranged $0.09-0.20 \mathrm{~g} \mathrm{~m}^{-3}$ from 2002 to 2005 before increasing to $0.35 \mathrm{~g} \mathrm{~m}^{-3}$ in wet season of 2004 . Seasonally averaged DIN concentrations decreased in both dry and wet seasons from 2006 to 2008. Over all seasonal budgets, the concentration of DIN in the SLE increased linearly from 0.0 to $0.38 \mathrm{~g} \mathrm{~m}^{-3}$ as external loading approached $0.20 \mathrm{~g} \mathrm{~N} \mathrm{~m}^{-2} \mathrm{~d}^{-1}$ $\left(r^{2}=0.85\right.$; Fig. $\left.5 b\right)$. The relationship between flushing time and DIN suggested that concentrations in the SLE declined hyperbolically reaching a minimum of $0.1 \mathrm{~g} \mathrm{~m}^{-3}$ when $T_{\mathrm{f}}$ $>10 \mathrm{~d}$ (Fig. 6b). Wet season DIP concentrations were generally 2.5 times greater than in the dry seasons of 2002-2008

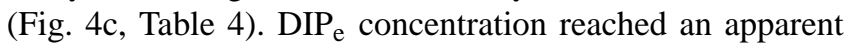
saturation at $0.20 \mathrm{~g} \mathrm{~m}^{-3}$ with increased external DIP loading $\left(\mathrm{DIP}_{\mathrm{Q}}\right)$ ranging up to $0.4 \mathrm{~g} \mathrm{~N} \mathrm{~m}^{-2} \mathrm{~d}^{-1}$ (Fig. 5c). The hyperbolic relationship for DIP $\mathrm{e}_{\mathrm{e}}$ was inverted when $T_{\mathrm{f}}$ served as the independent variable with concentrations declining as flushing time was $>10 \mathrm{~d}$ (Fig. 6c).

DIN was produced within the SLE $(\triangle D I N>0.0)$ in the 2002, 2004 and 2005 wet seasons (Fig. 7a). DIN was consumed $(\triangle \mathrm{DIN}<0.0)$ by the estuary in the wet seasons of 2003 and 2006 and the dry seasons of 2004 and 2005 (Table 4). Internal DIN production increased slightly with 
Table 5. Comparisons among attributes of CRE and SLE. Rate values were averaged across all DIP and DIN budgets derived for each estuary (2002-2008). Shown are estuary surface area, flushing time $\left(T_{\mathrm{f}}\right)$, freshwater discharge $(Q)$, daily DIP and DIN loading $\left(\mathrm{DIP} \mathrm{Q}_{\mathrm{Q}}\right.$ and $\mathrm{DIN}_{\mathrm{Q}}$ ), internal production (+) or consumption $(-)$ of DIP and DIN ( $\triangle \mathrm{DIP}$ and $\left.\triangle \mathrm{DIN}\right)$, net ecosystem metabolism (NEM), and the relative difference between nitrogen fixation and denitrification $\left(\mathrm{N}_{\text {fix }} \mathrm{D}>0.0=\right.$ net $\mathrm{N}_{2}$ fixation; $\mathrm{N}_{\text {fix }} \mathrm{D}<0.0=$ net denitrification). The final row provides the trophic status in terms of production vs. respiration $(+\mathrm{NEM}=p>r=$ autotrophic; $-\mathrm{NEM}=p<r=$ heterotrophic). The final column provides the ratio of values between the estuaries (CRE : SLE) in terms of surface area, $T_{\mathrm{f}}, \mathrm{Q}_{\mathrm{a}}$ and $\mathrm{DIP} \mathrm{P}_{\mathrm{Q}}$ and DIN $\mathrm{Q}$.

\begin{tabular}{llrrr}
\hline Attribute & Unit & CRE & SLE & CRE: SLE \\
\hline Surface Area & $\mathrm{km}^{2}$ & 56 & 22 & 2.5 \\
$T_{\mathrm{f}}$ & $\mathrm{d}$ & 18.4 & 11.4 & 1.6 \\
$\mathrm{Q}$ & $10^{6} \mathrm{~m}^{3} \mathrm{~d}^{-1}$ & 6.3 & 3.1 & 2.0 \\
$\mathrm{DIP}$ & $\mathrm{g} \mathrm{P} \mathrm{m}_{\mathrm{Q}} \mathrm{d}^{-1}$ & 0.003 & 0.005 & 0.6 \\
$\mathrm{DIN} \mathrm{Q}$ & $\mathrm{g} \mathrm{N} \mathrm{m}^{-2} \mathrm{~d}^{-1}$ & 0.005 & 0.007 & 0.7 \\
\hline \multirow{2}{*}{$\mathrm{DIP}$} & $\mathrm{g} \mathrm{P} \mathrm{m}^{-2} \mathrm{~d}^{-1}$ & 0.014 & -0.031 & \\
$\Delta \mathrm{DIN}$ & $\mathrm{g} \mathrm{N} \mathrm{m}^{-2} \mathrm{~d}^{-1}$ & 0.055 & 0.002 & \\
\hline NEM & $\mathrm{g} \mathrm{C} \mathrm{m}^{-2} \mathrm{~d}^{-1}$ & -0.544 & 1.171 & \\
$\mathrm{~N}_{\text {fix }} \mathrm{D}$ & $\mathrm{g} \mathrm{N} \mathrm{m}^{-2} \mathrm{~d}^{-1}$ & -0.043 & 0.228 & \\
Trophic Status & $p$ vs. $r$ & heterotrophic & autotrophic & \\
\hline
\end{tabular}

Table 6. Summary of average DIP and DIN loadings $\left(\mathrm{DIP}_{\mathrm{Q}}\right.$ and $\left.\mathrm{DIN}_{\mathrm{Q}}\right)$ and system DIP $(\Delta \mathrm{DIP})$ and DIN $(\Delta \mathrm{DIN})$ production $(+)$ or consumption (-) from several studies using the LOICZ methods. Similar units were derived among the studies for loadings (moles $\mathrm{m}^{-2} \mathrm{yr}^{-1}$ ) and production/consumption ( $\mathrm{mmol} \mathrm{m}^{-2} \mathrm{yr}^{-1}$ ). Studies with daily rates were multiplied by 182.5 days to calculate seasonal values that were summed to derive annual estimates. Studies reporting a single daily rate were multiplied by 365 days to derive annual estimates.

\begin{tabular}{|c|c|c|c|c|c|c|c|}
\hline \multirow[b]{2}{*}{ Reference } & \multirow[b]{2}{*}{ Estuary } & \multirow[b]{2}{*}{ Size $\left(\mathrm{km}^{2}\right)$} & \multirow[b]{2}{*}{$T_{\mathrm{f}}$ (days) } & \multirow{2}{*}{$\begin{array}{r}\mathrm{DIP}_{\mathrm{Q}} \\
\mathrm{mol} \mathrm{m}^{-2} \mathrm{yr}^{-1}\end{array}$} & \multirow{2}{*}{$\begin{array}{r}\Delta \mathrm{DIP} \\
\mathrm{mmol} \mathrm{m}^{-2} \mathrm{yr}^{-1}\end{array}$} & \multirow{2}{*}{$\frac{\mathrm{DIN}_{\mathrm{Q}}}{\mathrm{mol} \mathrm{m}^{-2} \mathrm{yr}^{-1}}$} & \multirow{2}{*}{$\begin{array}{r}\Delta \mathrm{DIN} \\
\mathrm{mmol} \mathrm{m}^{-2} \mathrm{yr}^{-1}\end{array}$} \\
\hline & & & & & & & \\
\hline \multirow[t]{4}{*}{ Que et al., 2003} & Lake Illawarra, Australia $^{\mathrm{a}}$ & 35 & & & & & \\
\hline & LIA, 1995 & & & & 1.37 & & 26.5 \\
\hline & Miller, 1998 & & 56 & & 7.43 & & -119.9 \\
\hline & $\mathrm{Qu}, 2001$ & & 33 & & 12.43 & & -85.8 \\
\hline Hung and Huang, 2005 & Tsengwen Estuary, Taiwan & $2,3,4^{\mathrm{b}}$ & $150,4.5,1^{\mathrm{b}}$ & & -83.0 & & -4484.6 \\
\hline Gazeau et al., 2005 & Randers Fjord, Denmark & 23 & 13 & & 65.7 & & \\
\hline Boonphakdee and Fujiwara, 2008 & Bangakong Estuary, Thailand & $\sim 23$ & 15.2 & & 109.5 & & 930.8 \\
\hline \multirow[t]{4}{*}{ Giordani et al,. 2008} & LOICZ and Italian lagoons ${ }^{\mathrm{c}}$ & & & & & & \\
\hline & $\mathrm{LOICZ}_{1}(n=94)$ & $<2500$ & & 0.31 & 146.5 & 5.3 & 2423.0 \\
\hline & $\operatorname{LOICZ}_{2}(n=61)$ & & & 0.11 & 35.3 & 2.4 & -813.0 \\
\hline & LaguNet $(n=17)$ & & $2 \mathrm{~d}$ to $3 \mathrm{yr}^{\mathrm{c}}$ & 0.04 & -13.7 & 1.2 & -761.0 \\
\hline \multirow{3}{*}{$\begin{array}{l}\text { Noriega and Araujo, } 2011 \\
\text { This Study }\end{array}$} & Barra da Jangandas Estuary, Brazil & 13 & $8-16$ & 0.11 & 2190.5 & 0.03 & -1292.8 \\
\hline & CRE & 57 & 18.4 & 0.08 & 159.6 & 0.41 & 1429.9 \\
\hline & SLE & 22 & 11.3 & 0.65 & -367.2 & 0.97 & 63.0 \\
\hline
\end{tabular}

external $\mathrm{DIN}_{\mathrm{Q}}$ up to a maximum loading rate of $0.18 \mathrm{~g}$ $\mathrm{N} \mathrm{m}^{-2} \mathrm{~d}^{-1}$ in the wet season of 2004 (Fig. 8a). Net estuarine DIN production/consumption hovered near $0.0 \mathrm{~g} \mathrm{~N} \mathrm{~m}^{-2} \mathrm{~d}^{-1}$ when $T_{\mathrm{f}} \geq 10 \mathrm{~d}$ (Fig. 9a).

$\triangle \mathrm{DIP}$ within the SLE was more variable and revealing than $\Delta$ DIN. The SLE generally produced DIP $(\Delta \mathrm{DIP}>0.0)$ in the wet seasons of 2002-2004 (Fig. 7b; Table 4). However, DIP was consumed $(\triangle \mathrm{DIP}<0.0)$ at rates of -0.05 to $-0.30 \mathrm{~g} \mathrm{P} \mathrm{m}^{-2} \mathrm{~d}^{-1}$ in 2005 and the dry season of 2006 . Internal DIP consumption became more negative as $\mathrm{DIP}_{\mathrm{Q}}$ increased to $0.4 \mathrm{~g} \mathrm{P} \mathrm{m}^{-2} \mathrm{~d}^{-1}$ (Fig. 8b). Similar to DIN dynamics, $\Delta$ DIP was near zero when $T_{\mathrm{f}} \geq 10 \mathrm{~d}$ (Fig. 9b). NEM was inverse to internal DIP consumption with maximum val- ues of 1.0-12.0 $\mathrm{g} \mathrm{C} \mathrm{m}^{-2} \mathrm{~d}^{-1}$ (Fig. 7c) that increased linearly with the external DIP load (Fig. 8c). Thus, both $\triangle \mathrm{DIP}$ and NEM approached 0.0 when $T_{\mathrm{f}} \geq 10 \mathrm{~d}$ (Fig. 9b, c). The average relative difference between $\mathrm{N}_{2}$ fixation and denitrification $\left(\mathrm{N}_{\mathrm{fix}} \mathrm{D}\right)$ was positive in both dry $\left(0.109 \mathrm{~g} \mathrm{~N} \mathrm{~m}^{-2} \mathrm{~d}^{-1}\right)$ and wet seasons $\left(0.347 \mathrm{~g} \mathrm{~N} \mathrm{~m}^{-2} \mathrm{~d}^{-1}\right)$ in the SLE (Table 4). The proportion of $\mathrm{N}_{2}$ fixation $\left(\mathrm{N}_{\mathrm{fix}} \mathrm{D}>0.0\right)$ increased linearly with NEM, which increased with external DIP loading (Fig. 10a). Closer inspection revealed that SLE ecosystem metabolism may be sensitive to the DIN : DIP loading ratio as NEM $\left(\mathrm{g} \mathrm{C} \mathrm{m}^{-2} \mathrm{~d}^{-1}\right)$ and relative $\mathrm{N}_{2}$ fixation $\left(\mathrm{g} \mathrm{N} \mathrm{m}^{-2} \mathrm{~d}^{-1}\right)$ decreased to $<0.0$ when the molar ratio of externally supplied nutrients was 3:1 (Fig. 10b, c). The wet season of 

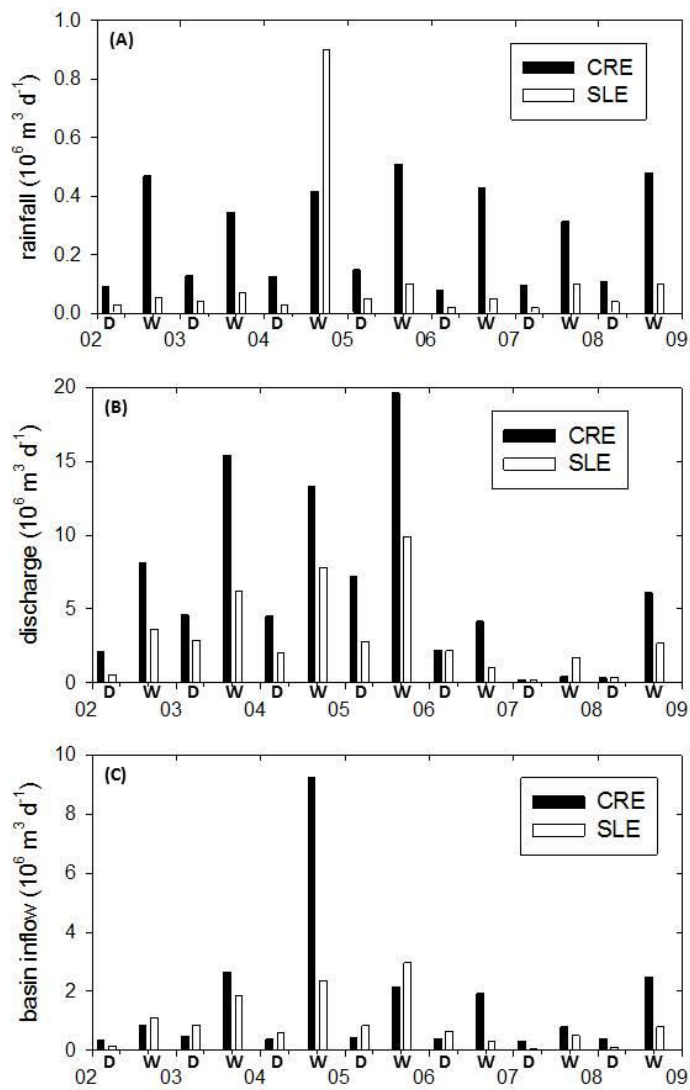

Fig. 3. Comparative seasonal time series of water budget components for CRE and SLE. CRE (filled) and SLE (open) bars are paired seasonally with the first pair of each year representing the dry season. All values are in $10^{6} \mathrm{~m}^{3} \mathrm{~d}^{-1}$. (A) Rainfall; (B) discharge; (C) basin inflow $=$ tributaries + ground water.

2005 had the lowest DIN : DIP loading ratio $(\sim 1.0)$, the most $\operatorname{NEM}\left(\sim 12 \mathrm{~g} \mathrm{C} \mathrm{m}^{-2} \mathrm{~d}^{-1}\right)$, and the greatest relative $\mathrm{N}$ fixation $\left(\sim 2.2 \mathrm{~g} \mathrm{~N} \mathrm{~m}^{-2} \mathrm{~d}^{-1}\right)$

\section{Discussion}

The Caloosahatchee and St. Lucie estuaries on opposite sides of Florida are small, sub-tropical water bodies with highly modified watersheds (Barnes, 2005; Sime, 2005). While natural variations in freshwater inflow and associated salinity changes are part of estuarine dynamics, anthropogenic modification of water delivery to afford flood protection and public safety can create unstable salinity distributions that adversely affect estuarine biota. The direct physical consequences of high flow events in the wet season can lead to low salinity throughout both of these estuaries. Rapid decreases in salinity can make it difficult for benthic organisms such as oysters and seagrass to survive (Buzzellli et al., 2012, 2013a). Conversely, periods with low freshwater input indicative of the dry season permits upstream in-
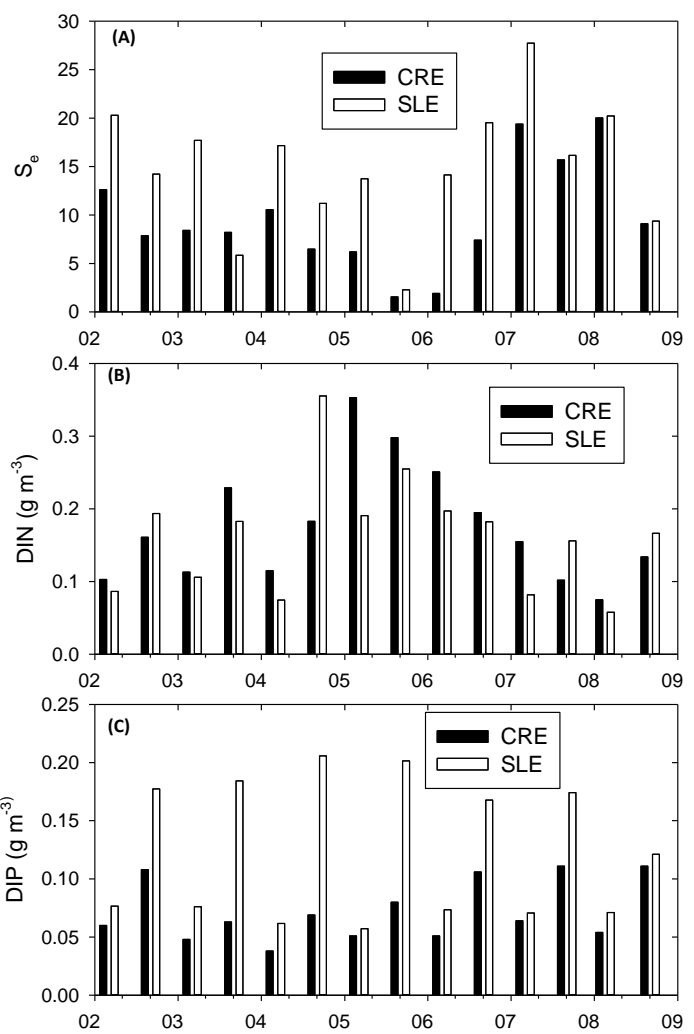

Fig. 4. Comparative seasonal time series of water budget components for CRE and SLE. CRE (filled) and SLE (open) bars are paired seasonally with the first pair of each year representing the dry season. (A) Salinity; (B) DIN $\left(\mathrm{g} \mathrm{m}^{-3}\right)$; (C) DIP $\left(\mathrm{g} \mathrm{m}^{-3}\right)$.

trusion of saltier water that endangers estuarine organisms with freshwater-dependent life cycles (Adams et al., 2009; Tolley et al., 2010; Simpfendorfer et al., 2011). Although both coastal water bodies possess similar watershed patterns of agriculture and urbanization and ranges in flushing time, these two estuaries have very different biogeochemical attributes (Table 5).

This study demonstrated that the CRE responded to external DIN loading by producing internal DIN at an average rate of $1429 \mathrm{mmol} \mathrm{m}^{-2} \mathrm{yr}^{-1}$ (Table 6). A similar result was reported for the $23 \mathrm{~km}^{2}$, sub-tropical Bangakong Estuary in Thailand $\left(930.8 \mathrm{mmol} \mathrm{m}^{-2} \mathrm{yr}^{-1}\right)$, which has a flushing time of $15.2 \mathrm{~d}$ (Table 6; Boonphakdee and Fujiwara, 2008). It is likely that the increased concentration of DIN in the CRE during the wet season was due to heightened rates of remineralization and denitrification in response to increased DIN loading and primary production. In contrast, estuaries in Australia (Lake Illawarra), Taiwan (Tsesngwen Estuary), and Italy (several lagoons) responded to DIN loading by consuming DIN on annual timescales (Que et al., 2003; Hung and Huang, 2005; Giordani et al., 2008, Noriega and Araujo, 2011). 

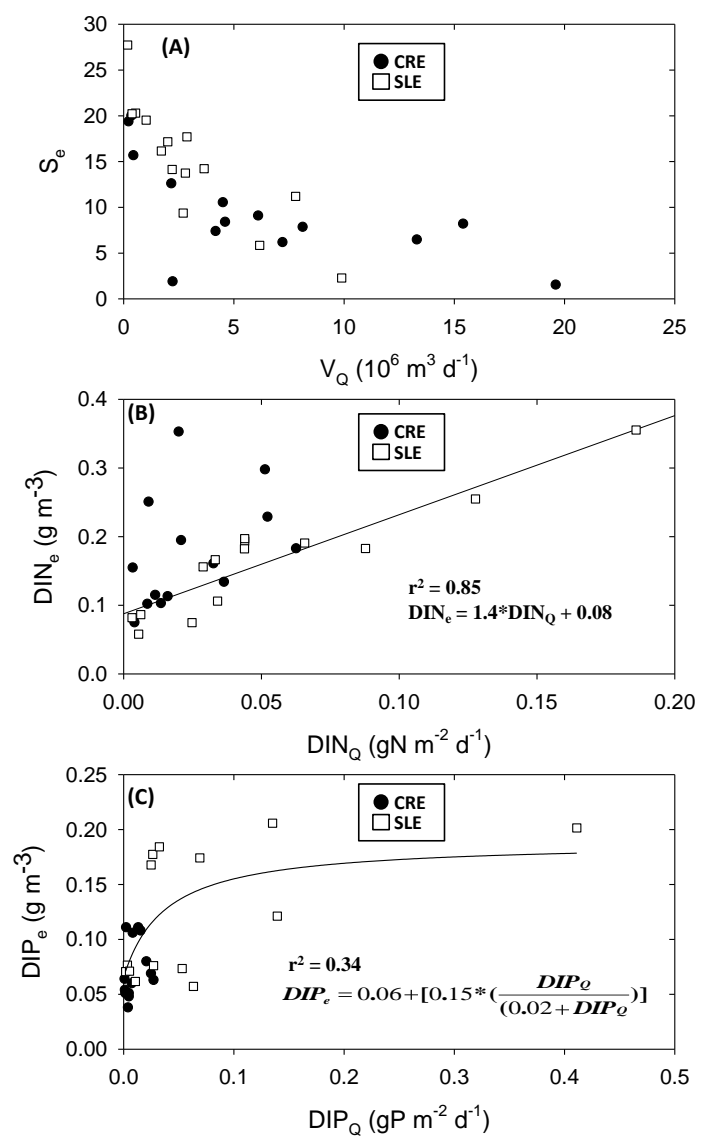

Fig. 5. Scatter plots from seasonal DIN and DIP budgets for CRE and SLE from 2002 to 2008. (A) Freshwater discharge $\left(V_{\mathrm{Q}}\right)$ vs. estuary salinity; (B) external DIN load $\left(\mathrm{g} \mathrm{N} \mathrm{m}^{-2} \mathrm{~d}^{-1}\right)$ vs. estuary DIN concentration $\left(\mathrm{g} \mathrm{m}^{-3}\right)$; (C) external DIP load $\left(\mathrm{g} \mathrm{P} \mathrm{m}^{-2} \mathrm{~d}^{-1}\right)$ vs. estuary DIP concentration $\left(\mathrm{g} \mathrm{m}^{-3}\right)$. Regression lines, $r^{2}$ values, and equations provided for the SLE points only.

Compared to the CRE, the response of the SLE to DIN loading was less clear with $\mathrm{N}_{2}$ fixation in excess of denitrification for all seasonal budgets. Empirical measurements of denitrification from both estuaries reinforced the notion that denitrification is an important sink for nitrogen in the CRE but not the SLE (Table 5; Howes et al., 2008, b). It is suspected that biogeochemical feedbacks including coupling of nitrification-denitrification at the sediment-water interface could account for the observed differences between the CRE and SLE (Kemp et al., 2005). The water column is more isolated from the benthos in the SLE due to the presence of muck-like sediments and considerably reduced light penetration across the estuary (Sime, 2005; Buzzelli et al., 2013b). Since LOICZ results are dependent upon stoichiometric assumptions and DIP dynamics, it is possible that DIN budgets are confounded in benthic-dominated estuaries with low DIN concentrations and significant denitrification (Swaney et al., 2011). This could be the case for the CRE.
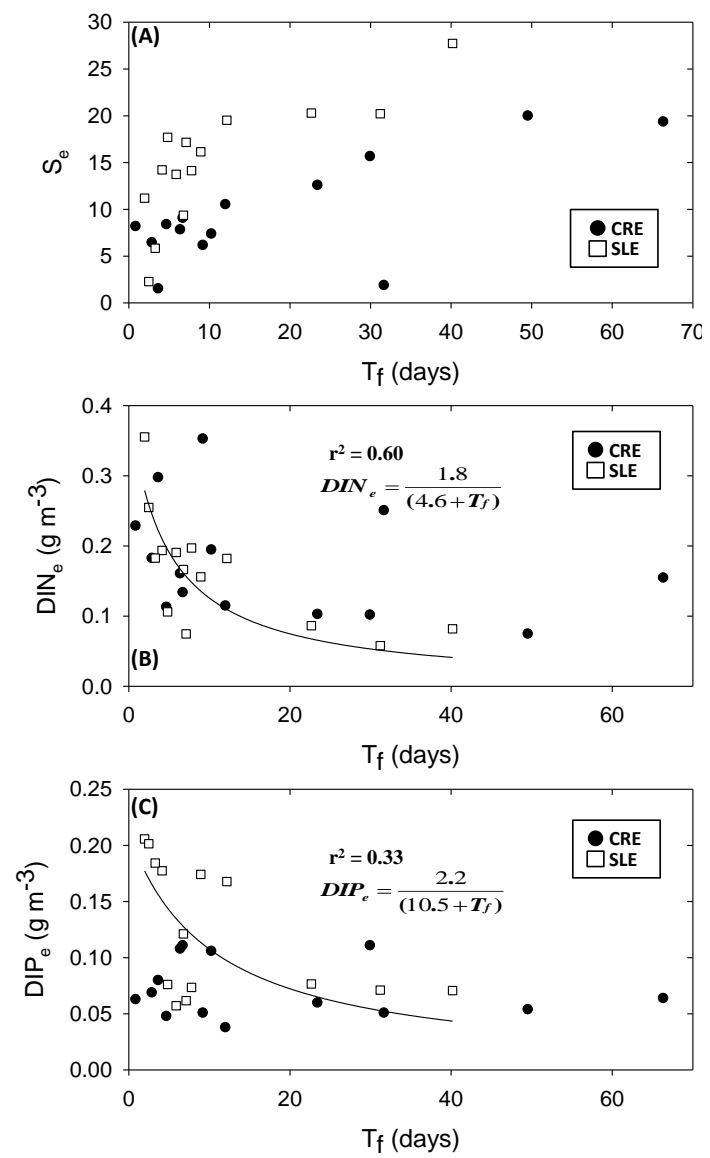

Fig. 6. Scatter plots from seasonal DIN and DIP budgets for CRE and SLE from 2002 to 2008 . Estimated flushing time ( $T_{\mathrm{f}}$; days) provided the independent variable vs. (A) salinity; (B) estuary DIN concentration $\left(\mathrm{g} \mathrm{m}^{-3}\right)$; $(\mathbf{C})$ estuary DIP concentration $\left(\mathrm{g} \mathrm{m}^{-3}\right)$. Regression lines, $r^{2}$ values, and equations provided for the SLE points only.

The budgets revealed that the internal production of $\mathrm{C}$, $\mathrm{N}$, and $\mathrm{P}$ was more influenced by external loading to the SLE than the CRE. While the CRE is 2.5 times larger and receives twice the freshwater inflow, spatially normalized DIP and DIN loadings are only $60-70 \%$ of those to the SLE (Table 5). Water column DIP concentrations, DIP consumption, and system autotrophy increased with external DIP loading to the SLE. A similar positive relationship between DIP loading and net primary production has been reported for an estuary in Taiwan and several eutrophied Italian lagoons (Table 6; Hung and Huang, 2005; Giordani et al., 2008). In contrast, annual estimates of $\Delta D I P$ were positive in estuaries such as Randers Fjord, Denmark (65.7 $\mathrm{mmol} \mathrm{m}^{-2} \mathrm{yr}^{-1}$; Gazeau et al., 2005); Bangakong Estuary, Thailand $\left(109.5 \mathrm{mmol} \mathrm{m}^{-2} \mathrm{yr}^{-1}\right.$; Boonphakdee and Fujiwara, 2008); and the CRE (159.6 $\mathrm{mmol} \mathrm{m}^{-2} \mathrm{yr}^{-1}$; this study). Although drainage and discharge typically deliver much of the $\mathrm{P}$ required for primary production in south 

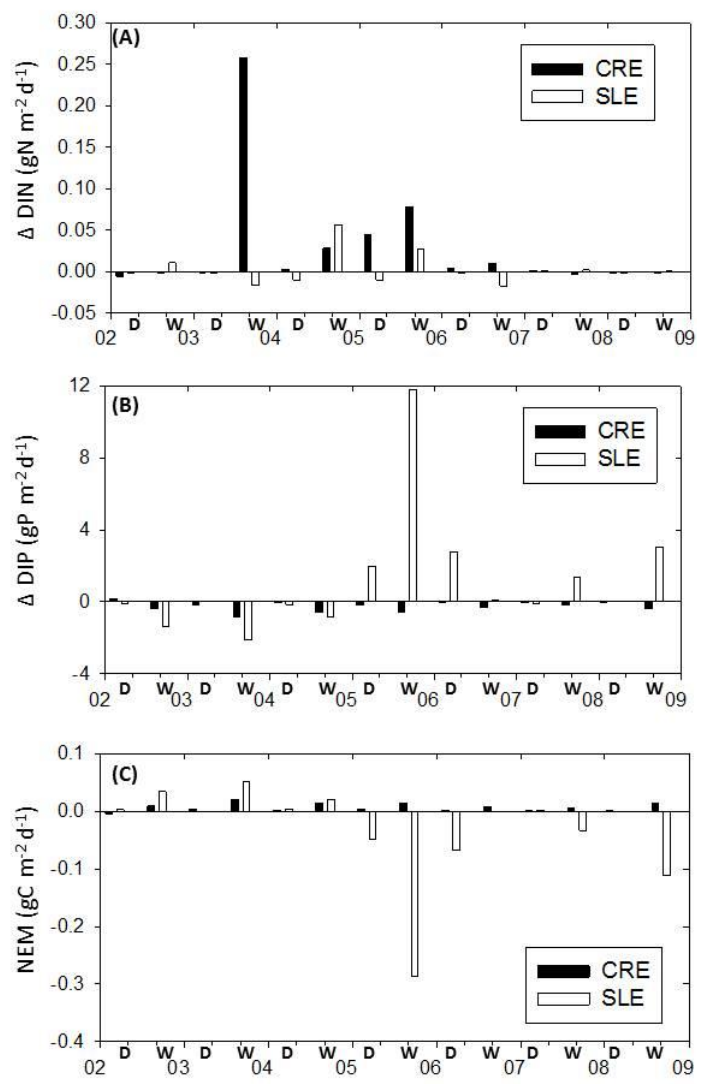

Fig. 7. Comparative seasonal time series of internal CNP source/sink processing for CRE and SLE. CRE (filled) and SLE (open) bars are paired seasonally with the first pair of each year representing the dry season. (A) $\Delta$ DIN $\left(\mathrm{g} \mathrm{N} \mathrm{m}^{-2} \mathrm{~d}^{-1}\right)$; (B) $\Delta$ DIP $\left(\mathrm{g} \mathrm{P} \mathrm{m}^{-2} \mathrm{~d}^{-1}\right)$; (C) NEM $\left(\mathrm{g} \mathrm{C} \mathrm{m}^{-2} \mathrm{~d}^{-1}\right)$.

Florida estuaries (Koch et al., 2011), there is additional potential for eutrophication of the SLE through combined water column and benthic regeneration of DIP that fuels primary production (Buzzelli et al., 2013b).

The magnitude of freshwater, DIN, and DIP inputs relative to the flushing time provide the setting for interesting biogeochemical dynamics in the SLE (Dettman 2001; Sheldon and Alber, 2006). In the absence of freshwater inflow, the flushing time of the SLE is approximately $20 \mathrm{~d}$ solely through tidal exchange (Y. Wan and D. Sun, unpublished data). Nutrient budget results suggested that both the concentrations and internal utilization of DIP and DIN stabilized with flushing times greater than $10 \mathrm{~d}$. Longer water residence times allow for increased grazing and sedimentation to respond to primary production and balance system metabolism (Buzzelli et al., 2007; Lucas et al., 2009; Phlips et al., 2011; Swaney et al., 2011). In fact, it appears that the negative relationship between flushing time and NEM observed in this study is a common attribute of many estuaries (Fig. 11). If $T_{\mathrm{f}}$ in the SLE is $<10 \mathrm{~d}$ as it is much of the time (Ji et al., 2007), then the inputs of freshwater and nu-
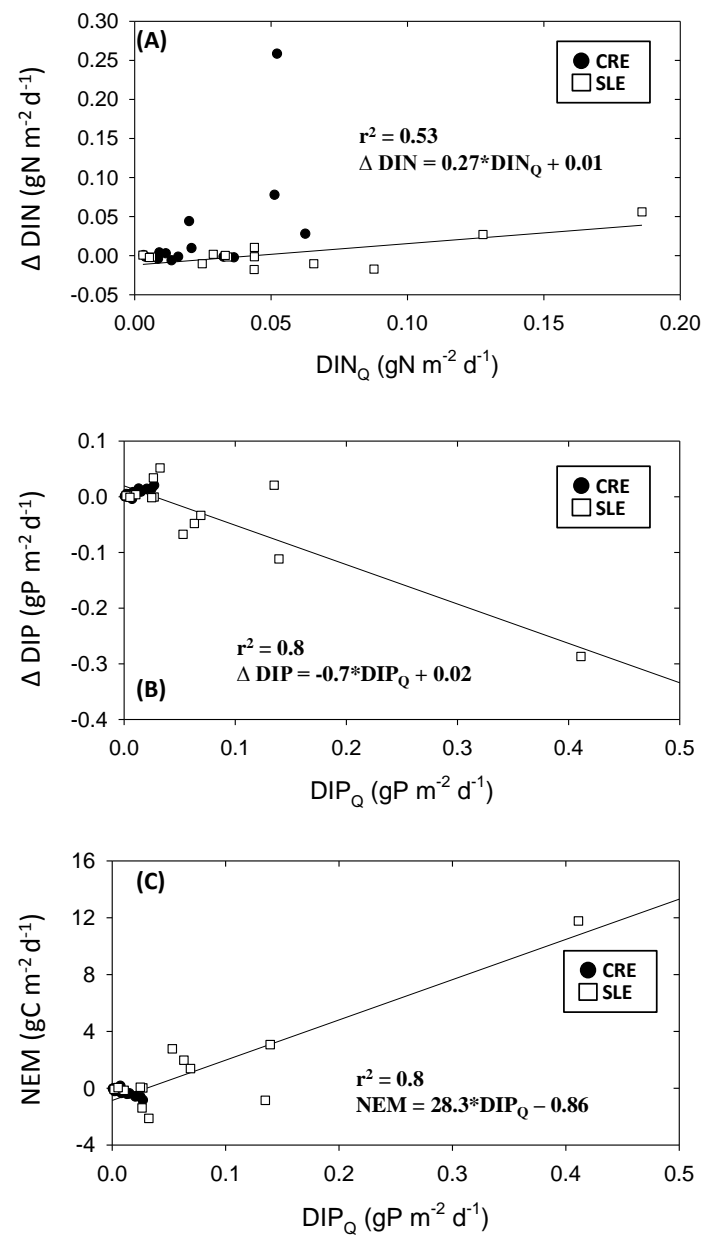

Fig. 8. Scatter plots from seasonal DIN and DIP budgets for CRE and SLE from 2002 to 2008. (A) $\Delta$ DIN $\left(\mathrm{g} \mathrm{N} \mathrm{m}^{-2} \mathrm{~d}^{-1}\right)$; (B) $\Delta$ $\operatorname{DIP}\left(\mathrm{g} \mathrm{P} \mathrm{m}^{-2} \mathrm{~d}^{-1}\right)$; (C) NEM $\left(\mathrm{g} \mathrm{C} \mathrm{m}^{-2} \mathrm{~d}^{-1}\right)$. External DIN load (g $\left.\mathrm{N} \mathrm{m}^{-2} \mathrm{~d}^{-1}\right)$ or DIP load $\left(\mathrm{g} \mathrm{P} \mathrm{m}^{-2} \mathrm{~d}^{-1}\right)$ provided the independent variable. Regression lines, $r^{2}$ values, and equations provided for the SLE points only.

trients result in rapid DIP consumption, a spike in autotrophy, increased $\mathrm{N}_{2}$ fixation, and the potential for DIN export to the coastal ocean. For example, rates of estuarine DIP consumption $\left(-3.0 \mathrm{~g} \mathrm{P} \mathrm{m}^{-2} \mathrm{~d}^{-1}\right)$, NEM $\left(12 \mathrm{~g} \mathrm{C} \mathrm{m}^{-2} \mathrm{~d}^{-1}\right)$, and $\mathrm{N}_{\text {fix }} \mathrm{D}\left(2.3 \mathrm{~g} \mathrm{~N} \mathrm{~m}^{-2} \mathrm{~d}^{-1}\right)$ were all maximized in the wet season of 2005. In the case of extreme freshwater inflows and rapid flushing $\left(T_{\mathrm{f}}<1 \mathrm{~d}\right)$, both allochthonous and autochthonous materials are transported from the estuary to the coastal ocean (Doering et al., 2006; Murrell et al., 2007; Phlips et al., 2011). Reliable estimates of freshwater inflow and nutrients along with knowledge of flushing time offer a platform to quantify and link external loading to internal ecosystem metabolism (Fig. 11; Dettmann, 2001; Sheldon and Alber, 2006; Swaney et al., 2011).

Nitrogen limitation of phytoplankton in controlled bioassays on daily timescales suggested that reductions in 

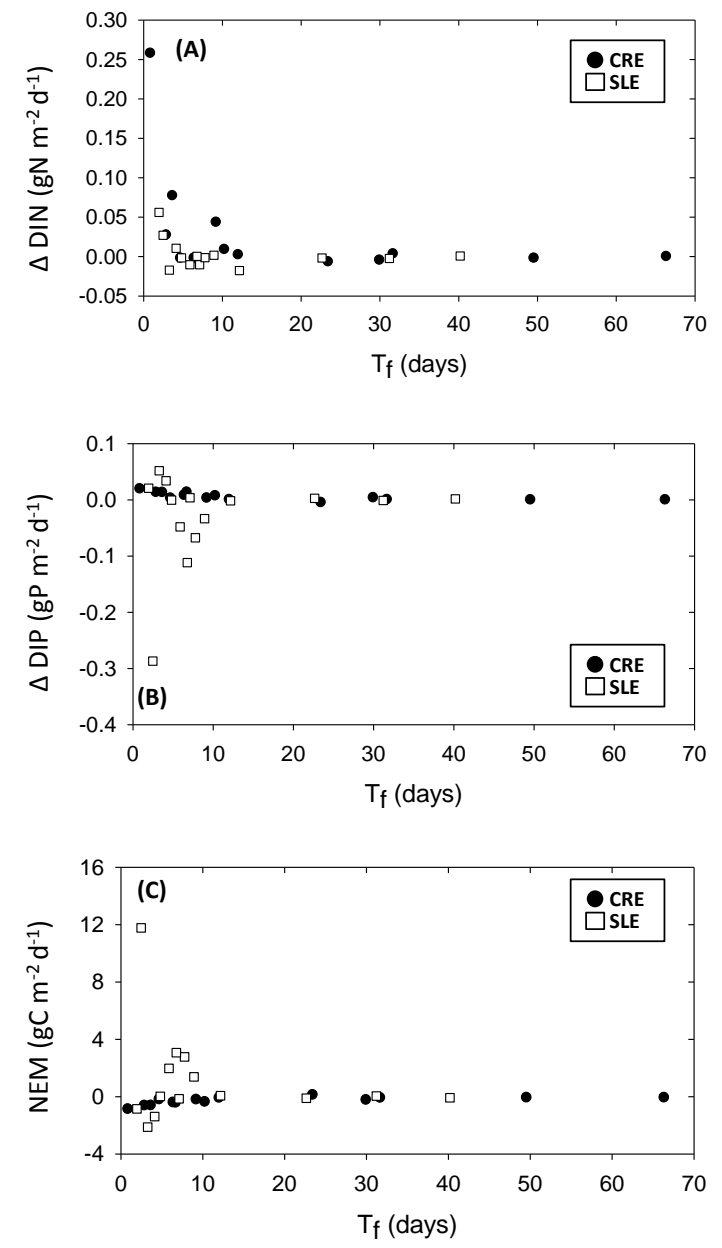

Fig. 9. Scatter plots from seasonal DIN and DIP budgets for CRE and SLE from 2002 to 2008. Estimated flushing time ( $T_{\mathrm{f}}$; days) provided the independent variable vs. (A) $\triangle \mathrm{DIN}\left(\mathrm{g} \mathrm{N} \mathrm{m}^{-2} \mathrm{~d}^{-1}\right) ;($ (B) $\Delta \mathrm{DIP}\left(\mathrm{g} \mathrm{P} \mathrm{m}^{-2} \mathrm{~d}^{-1}\right)$; (C) NEM $\left(\mathrm{g} \mathrm{C} \mathrm{m}^{-2} \mathrm{~d}^{-1}\right)$.

$\mathrm{N}$ loading could decrease primary production in the SLE (Phlips et al., 2011). This result is reasonable given that $\mathrm{N}$ has been emphasized as the dominant limiting nutrient in estuaries (Howarth and Marino, 2006). However, the extrapolation of knowledge gained from fine-scale experiments to the seasonal estuary scale may not be appropriate because of feedbacks related to internal biogeochemical cycling (Kemp et al., 2005; Wulff et al., 2011). This may be particularly true for $\mathrm{N}$ and $\mathrm{P}$ recycling within the SLE where there is surplus DIN produced under increased DIP loading. While increased freshwater inflow could provide the DIP required for $\mathrm{N}_{2}$ fixation, it is possible that benthic nitrogen fixation may be inhibited by lack of light penetration in the SLE (Howarth and Marino, 2006; Buzzelli et al., 2013b). Despite the result that $\mathrm{N}_{2}$ fixation exceeded denitrification in the SLE, it is possible that $\mathrm{N}_{2}$ fixation may be negligible since the phytoplankton community is composed of diatoms and dinoflagellates (Millie et al., 2004; Phlips et al., 2011). Smith (1990) hy-
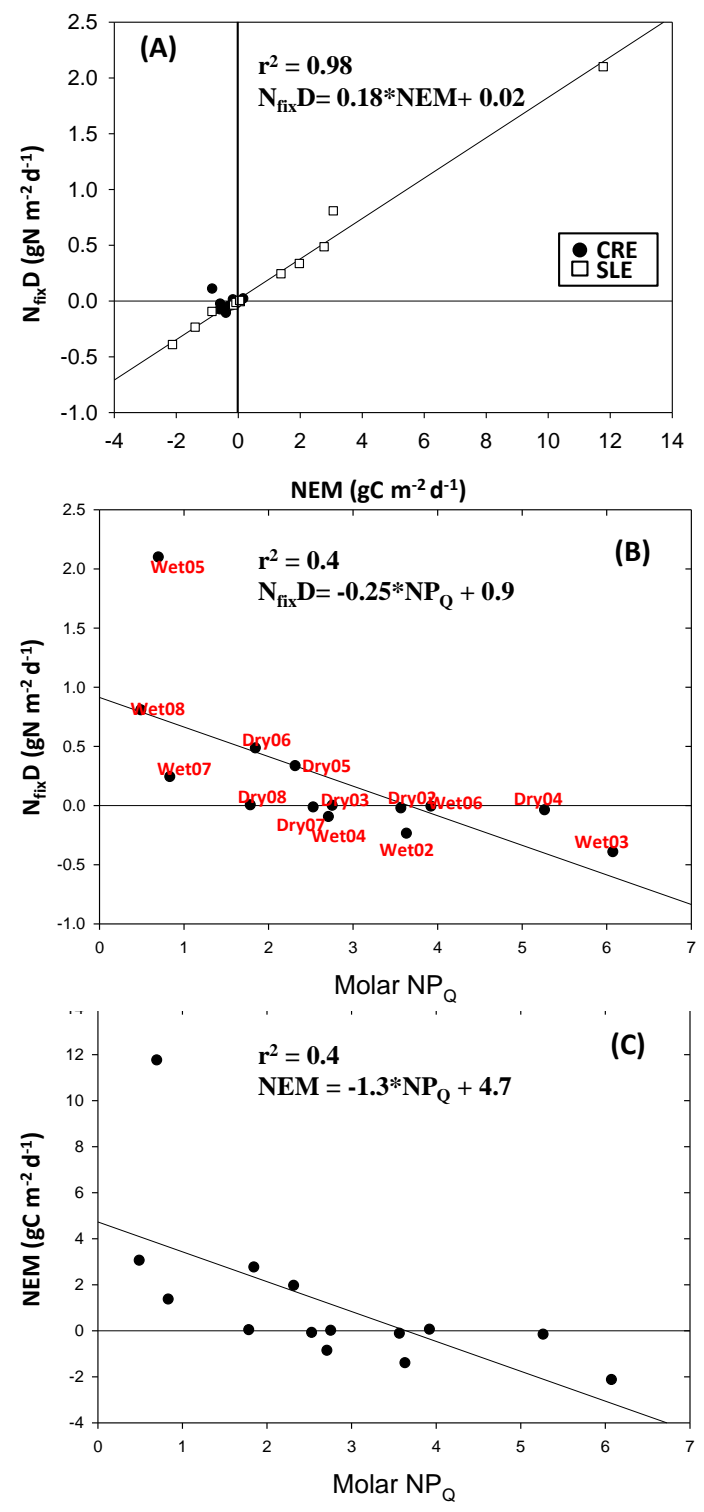

Fig. 10. Scatter plots from seasonal DIN and DIP budgets for CRE and SLE from 2002 to 2008. (A) Both the CRE (filled circles) and the SLE (open squares) presented with net ecosystem metabolism (NEM) vs. the difference between $\mathrm{N}_{2}$ fixation and denitrification $\left(\mathrm{N}_{\text {fix }} \mathrm{D}\right)$. Regression lines, $r^{2}$ values, and equations provided for the SLE points only. (B) Scatter plots of seasonal values from the SLE from 2002 to 2008. Relationship between the DIN : DIP ratio of loading (independent) and $\mathrm{N}_{\text {fix }} \mathrm{D}$ (dependent). (C) Relationship between the DIN : DIP ratio of loading as the independent variable and NEM as the dependent variable.

pothesized that when DIN supply is great, non-heterocystous phytoplankton can proliferate if provided with adequate $\mathrm{P}$ supply. This appears to be the case as the SLE experienced a huge bloom of the toxic, non-heterocystous cyanobacterium Microcystis aeruginosa with the extreme inputs of freshwater and nutrients in 2005 (Phlips et al., 2011). 


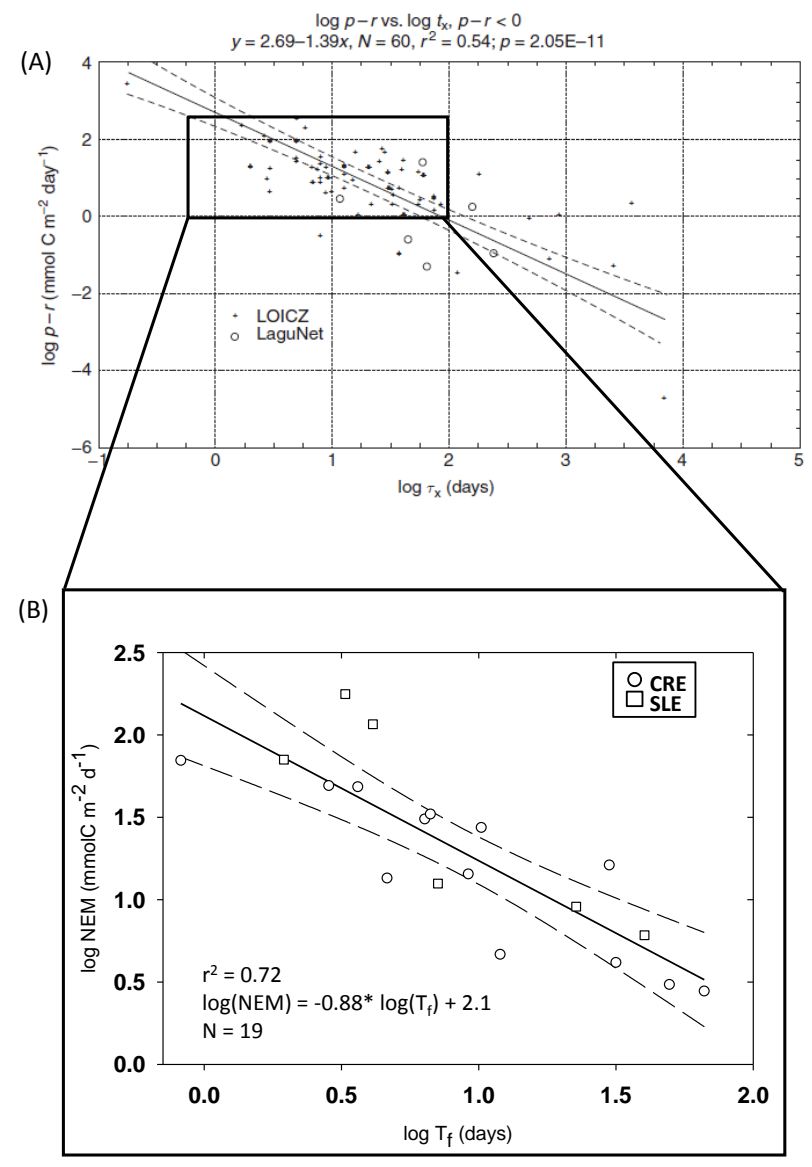

Fig. 11. Integrated results demonstrating the relationship between flushing time ( $T_{\mathrm{f}}$; days) and NEM $\left(\mathrm{mmol} \mathrm{C} \mathrm{m}{ }^{-2} \mathrm{~d}^{-1}\right)$. (A) Plot of estuaries from the LOICZ database with negative NEM, adopted with permission from Swaney et al. (2011). (B) Similar results from the CRE and SLE confined to seasonal budgets with negative NEM $\left(\mathrm{N}_{\mathrm{CRE}}=13 ; \mathrm{N}_{\mathrm{SLE}}=6\right)$. Values resulted from log transformation of the absolute values of NEM in each of the 19 cases. Provided are the linear regression information and $95 \%$ confidence intervals (dashed lines).

The recognition that sub-tropical estuaries have the potential to respond to both $\mathrm{N}$ and $\mathrm{P}$ inputs is an important step to establish nutrient load limits (Smith et al., 2006; Howarth and Marino, 2006; Wulff et al., 2011). However, merely setting criteria for either total or dissolved nutrient loading based on their correlation to water column concentrations fails to appreciate the complexity and uncertainty of estuarine biogeochemical cycling (Dodds, 2003). In both the discharge and the receiving basin, the DIN : DIP ratios are often very different than the TN : TP ratios due to the differential composition and reactivity of dissolved organic $\mathrm{N}$ and $\mathrm{P}$ (DON and DOP; Smith et al., 2005). The assessment of particulate and dissolved organic fractions of the TN and TP pools requires a modification of the existing LOICZ protocol (Hung and Huang, 2005).
Freshwater inflow to the SLE has a comparatively high $\mathrm{TN}$ : TP ratio $(\sim 14: 1)$, but a much reduced DIN : DIP ratio ( 3.0; Doering 1996; SFWMD 2012a). While most of the TP is available as DIP (DIP : TP $=0.7$ ), most of the TN is in the form of DON with DIN comprising only $30 \%$ of TN. It is possible that autochthonous DOP production and contribution to NEM could confound LOICZ results in some estuaries (Gazeau et al., 2005). DON is a potentially important component in CNP cycling in CRE, which possesses comparatively low concentrations of water column N (Hung and Huang, 2005; Eyre et al., 2011). Like many estuaries, there is limited understanding about the effects of DOP and DON cycling on primary production and system metabolism in the SLE and CRE (Smith and Hollibaugh, 2006; Loh, 2008). Future studies should examine the partitioning and reactivity of $\mathrm{TP}$ and TN external loading and internal concentrations including dissolved and particulate organic and inorganic fractions. Knowledge of the role and reactivity of TN and TP constituents would support the contention that the regulation of both nutrients should be considered (Smith, 2006; Paerl, 2009; Conley et al., 2009).

LOICZ was designed to estimate carbon metabolism for estuaries around the world where salinity and inorganic nutrient concentrations, and not biogeochemical rate processes, provided a bulk of the available data (Swaney et al., 2011). The approach assumes that estuaries can be represented as well-mixed, homogeneous boxes. This assumption creates the potential for errors if an estuary possesses spatial and/or vertical variability in conservative (salinity) and nonconservative (CNP) properties (Webster et al., 2000). While the CRE and the SLE are often well-mixed over depth, there can be horizontal gradients between the headwaters and the oceanic boundary during some inflow conditions (Buzzelli et al., 2013b). A modification that could improve the reliability of the LOICZ approach would be to split each estuary into segments based upon predominant salinity and nutrient gradients in the dry and wet seasons. To further refine the approach, in situ rates of dissolved CNP exchanges across the sediment-water interface for different years could be introduced to improve system-level calculations and estimates (Buzzelli et al., 2013b).

It is possible that generating LOICZ budgets using annually averaged data could increase the error inherent in the calculations (Webster et al., 2000). This potential source of error is mitigated in the present study due to the availability of intra-seasonal and intra-annual data used to develop the LOICZ nutrient budgets. Overall, estimates of external nutrient loading, estuarine flushing, and internal CNP cycling derived in this study should be viewed as highly reliable given the quantity and quality of the monitoring data and the predictable relationships between system physical attributes and biogeochemical signatures (Smith et al., 2005; Swaney et al., 2011). The observed relationship between flushing time and NEM is in agreement with that determined for a large number of estuaries where LOICZ was applied (Fig. 11). 
Smaller estuaries such as the CRE and SLE that are subjected to high material loading and fast flushing are very important components in biogeochemical cycling at the local, regional, and global scales (Smith et al., 2005). The LOICZ approach to estuarine nutrient budgets offers a highly transferrable method to link watershed inputs to biogeochemical responses for a variety of coastal embayments (Swaney et al., 2011). While the LOICZ approach has been applied to hundreds of coastal water bodies, its value to coastal management is dependent upon the quality of input data, the reliability of the steady-state and stoichiometric assumptions, and the connectivity between the watersheds and the estuaries (Smith et al., 2005; Swaney et al., 2011). This study provided an improved understanding of the relationships among seasonal variations in watershed $\mathrm{N}$ and $\mathrm{P}$ loading, hydrodynamic flushing time, nutrient cycling, and ecosystem metabolism for sub-tropical estuaries with heavily modified watersheds (Millie et al., 2004; Phlips et al., 2011; Eyre et al., 2011).

Acknowledgements. We would like to thank Kathy Haunert, Zhiquiang Chen, Detong Sun, Lucia Baldwin, Nenad Irichanin, and Daniel Crean for help in data acquisition. Yao Yan helped provided geographic expertise for map Figs. 1 and 2. A special acknowledgement goes to Dennis Swaney for valuable insight into the LOICZ approach and interpretation of results. We acknowledge the editorial efforts of P. Gorman, S. Gray, and R. T. James at the South Florida Water Management District and four anonymous reviewers.

Edited by: B. A. Bergamaschi

\section{References}

Adams, A. J., Wolfe, R. K., and Layman, C. A.: Preliminary examination of how human-driven freshwater flow alteration affects trophic ecology of juvenile snook (Centropomus undecimalis) in estuarine creeks, Estuar. Coast., 32, 819-828, 2009.

Antonini, G. A., Fann, D. A., and Roat, P.: A Historical Geography of Southwest Florida Waterways. Volume II; Placida Harbor to Marco Island, National Sea Grant College Program, College Park, MD, 1-16, 2002.

Barnes, T.: Caloosahatchee Estuary Conceptual Ecological Model, Wetlands, 25, 884-897, 2005.

Boonphakdee, T. and Fujiwara, T.: Temporal variability of nutrient budgets in a tropical river estuary: The Bangpakong River Estuary, Thailand, Environment Asia, 1, 7-21, 2008.

Brock, D. A.: Nitrogen budget for low and high freshwater inflows, Nueces Estuary, Texas, Estuaries, 24, 509-521, 2001.

Buranapratheprat, A., Yanagi, T., Boophakdee, T., and Sawangwong, P.: Seasonal variations in inorganic nutrient budgets of the Bangpakong Estuary, Thailand, J. Oceanogr., 58, 557-564, 2002.

Buzzelli, C., Holland, A. F., Sanger, D. S., and Conrads, P. C.: Hydrographic characterization of two tidal creeks with implications for watershed land use, flushing times, and benthic production, Estuar. Coast., 30, 321-330, 2007.

Buzzelli, C., Robbins, R., Doering, P., Chen, Z., Sun, D., Wan, Y., Welch, B., and Schwarzchild, A.: Monitoring and modeling of
Syringodium filiforme (Manatee Grass) in the southern Indian River Lagoon, Estuar. Coast., 35, 1401-1415, 2012.

Buzzelli, C., Parker, M., Geiger, S., Wan, Y., Doering, P., and Haunert, D.: Predicting system-scale impacts of oyster clearance on phytoplankton production in a small sub-tropical estuary, Environ. Model. Assess., 18, 185-198, 2013a.

Buzzelli, C., Chen, Z., Coley, T., Doering, P., Samimy, R., Schlezinger, D., and Howes, B.: Dry season sediment-water exchanges of nutrients and oxygen in two Florida estuaries: Patterns, comparisons, and internal loading, Florida Scientist, 76, 54-79, 2013b.

Chamberlain, R. H. and Doering, P. H.: Freshwater inflow to the Caloosahatchee Estuary and the resource-based method for evaluation, in: Proceedings of the Charlotte Harbor Public Conference and Technical Symposium, edited by: Treat, S. F., South Florida Water Management District, West Palm Beach, FL, 8190, 1998.

Childers , D. L., Boyer, J. N., Davis, S. E., Madden, C. J., Rudnick, D. T., and Sklar, F.: Relating precipitation and water management to nutrient concentrations in the oligotrophic "upside-down" estuaries of the Florida Everglades, Limnol. Oceanogr., 51, 602616, 2006.

Cloern, J. E.: Our evolving conceptual model of the coastal eutrophication problem, Mar. Ecol. Prog. Ser., 210, 223-253, 2001

Conley, D. J., Paerl, H. W., Howarth, R. W., Boesch, D. F., Seitzinger, S. P., Havens, K. E., Lancelot, C., and Likens, G. E.: Controlling eutrophication: Nitrogen and phosphorus, Science, 323, 1014-1015, 2009.

Dennison, W. C.: Environmental problem solving in coastal ecosystems: A paradigm shift to sustainability, Estuar. Coast. Shelf Sci., 77, 185-196, 2008.

Dettmann, E. H.: Effect of water residence time on annual export and denitrification of nitrogen in estuaries: A model analysis, Estuaries, 24, 481-490, 2001.

Dodds, W. K.: Misuse of inorganic N and soluble reactive P concentrations to indicate nutrient status of surface waters, J. North Amer. Benthol. Soc., 22, 171-181, 2003.

Doering, P. H.: Temporal variability of water quality in the St. Lucie Estuary, South Florida, Water Res. Bull., 32, 1293-1306, 1996.

Doering, P. H., Chamberlain, R., and Haunert, K. M.: Chlorophyll $\mathrm{a}$ and its use as an indicator of eutrophication in the Caloosahatchee Estuary, Florida, Florida Scientist, 69, 51-72, 2006.

Eyre, B., Ferguson, A. J. P., Webb, A., Maher, D., and Oakes, J. M.: Denitrification, $\mathrm{N}$-fixation, and nitrogen and phosphorus fluxes in different benthic habitats and their contribution to the nitrogen and phosphorus budgets of a shallow oligotrophic subtropical coastal system (southern Moreton Bay, Australia), Biogeochemistry, 102, 111-133, 2011.

Flemer, D. A. and Champ, M. A.: What is the future fate of estuaries given nutrient over-enrichment, freshwater diversion, and low flows?, Mar. Pollut. Bull., 52, 247-258, 2006.

Gazeau, F., Borges, A.V., Barron, C., Duarte, C.M., Iversen, N., Middleburg, J.J., Delille, B., Pizay, M.-D., Frankingnoulle, M., and Gattuso, J.-P.: Net ecosystem metabolism in micro-tidal estuary (Randers Fjord, Denmark): evaluation of methods, Mar. Ecol. Prog. Ser., 301, 23-41, 2005.

Giordani, G., Austoni, M., Zaldivar, J. M., Swaney, D. P., and Viaroli, P.: Modelling ecosystem functions and properties at different time and spatial scales in shallow coastal lagoons: An ap- 
plication of the LOICZ biogeochemical model, Estuar. Coast. Shelf Sci., 77, 264-277, 2008.

Gordon, D. C., Boudreau, P. R., Mann, K. H., Ong, J.-E., Silvert, W. L., Smith, S. V., Wattayakorn, G., Wulff, F., and Yanagi, T.: LOICZ Biogeochemical Modeling Guidelines, LOICZ/R\&S/955, Texel, the Netherlands, 1-96, 1996.

Howarth, R. W. and Marino, R.: Nitrogen as the limiting nutrient for eutrophication in coastal marine ecosystems: evolving views over three decades, Limnol. Oceanogr., 51, 364-376, 2006.

Howes, B. H., Schlezinger, D., and Samimy R.: The Characterization and Quantification of Benthic Nutrient Fluxes in the Caloosahatchee River and Estuary. Project Summary Report, Coastal Systems Program, School for Marine Science and Technology, University of Massachusetts Dartmouth, 2008a.

Howes, B. H., Schlezinger, D., and Samimy R.: The Characterization and Quantification of Benthic Nutrient Fluxes in the St. Lucie River and Estuary. Project Summary Report, Coastal Systems Program, School for Marine Science and Technology, University of Massachusetts Dartmouth, 2008b.

Hung, J. J. and Huang, M. H.: Seasonal variations in organic carbon and nutrient transport through a tropical estuary (Tsengwen) in southeastern Taiwan, Environ. Geochem. Health, 27, 75-95, 2005.

Ji, Z.-G., Hu, G., Shen, J., and Wan, Y.: Three-dimensional modeling of hydrodynamics processes in the St. Lucie Estuary, Estuar. Coast. Shelf Sci., 73, 188-200, 2007.

Kemp, W. M., Boynton, W. R., Adolf, J. E., Boesch, D. F., Boicourt, W. C., Brush, G., Cornwell, J. C, Fisher, T. R., Glibert, P. M., Hagy, J. D., Harding, L. W., Houde, E. D., Kimmel, D. G., Miller, W. D., Newell, R. I. E., Roman, M. R., Smith, E. M., and Stevenson, J. C.: Eutrophication of Chesapeake Bay: Historical trends and ecological interactions, Mar. Ecol. Prog. Ser., 303, 1-29, 2005.

Koch, G. R., Childers, D. L., Staehr, P. A., Price, R. M., Davis, S. E., and Gaiser, E. E.: Hydrological conditions control P loading and aquatic metabolism in an oligotrophic subtropical estuary, Estuar. Coast., 35, 335-352, doi:10.1007/s12237-011-9431$5,2011$.

Liu, S. M., Hong, G.-H., Zhang, J., Ye, X. W., and Jiang, X. L.: Nutrient budgets for large Chinese estuaries, Biogeosciences, 6 , 2245-2263, doi:10.5194/bg-6-2245-2009, 2009.

Loh, A.: Mixing and Degradation of Riverine Dissolved Organic Nitrogen in the Caloosahatchee Estuary. Final Report to the South Florida Water Management District, 35 pp., 2008.

Lucas, L. V., Thompson, J. K., and Brown, L. R.: Why are diverse relationships observed between phytoplankton biomass and transport time?, Limnol. Oceanogr., 54, 381-390, 2009.

Millie, D. F., Carrick, H. J., Doering, P. H., and Steidinger, K. A.: Intra-annual variability of water quality and phytoplankton in the North Fork of the St. Lucie River Estuary, Florida (USA): a quantitative assessment, Estuar. Coast. Shelf Sci., 61, 137-149, 2004.

Murrell, M., Hagy, J. D., Lores, E. M., and Greene, R. M.: Phytoplankton production and nutrient distributions in a subtropical estuary: Importance of freshwater flow, Estuar. Coast., 30, 390402, 2007

Nixon, S. W.: Coastal marine eutrophication: A definition, social causes, and future concerns, Ophelia, 41, 199-219, 1995.
Noriega, C. E. D. and Araujo, M.: Nutrient budgets (C, N, P) and trophic dynamics of a Brazilian tropical estuary: Barra das Jangadas, Ann. Braz. Ac. Sci., 83, 441-456, 2011.

Paerl, H. W.: Controlling eutrophication along the freshwatermarine continuum: Dual nutrient ( $\mathrm{N}$ and $\mathrm{P}$ ) reductions are essential, Estuar. Coast., 32, 593-601, 2009.

Phlips, E. J., Badylak, S., Hart, J., Haunert, D., Lockwood, J., O'Donnell, K., Sun, D., Viveros, P., and Yilmaz, M.: Climatic influences on autochthonous and allochthonous phytoplankton biomass in a subtropical estuary, St. Lucie Estuary, Florida, USA, Estuar. Coast., 35, 292-307, doi:10.1007/s/12237-011-9442-2, 2011.

RECOVER: System Status Report, Restoration Coordination and Verification Program, United States Army Corps of Engineers, Jacksonville, FL, and the South Florida Water Management District, West Palm Beach, FL, 2010.

Sackett, J. W.: Survey of the Caloosahatchee River, Florida. Report to the Captain of the United States Engineering Office, St. Augustine, Florida, 1888.

SFWMD: St. Lucie River Watershed Protection Plan 2012 Update, 2012 South Florida Environmental Report, Volume 1, Appendix 10-1, available at: www.sfwmd.gov/SFER, 2012a.

SFWMD: Caloosahatchee River Watershed Protection Plan 2012 Update, 2012 South Florida Environmental Report, Volume 1, Appendix 10-2, available at: www.sfwmd.gov/SFER, 2012b.

Sheldon, J. E. and Alber, M.: The calculation of estuarine turnover times using freshwater fraction and tidal prism methods: A critical evaluation, Estuaries and Coasts, 29, 133-146, 2006.

Sime, P.: St. Lucie Estuary and Indian River Lagoon Conceptual Ecological Model, Wetlands, 25, 898-207, 2005.

Simpfendorfer, C. A., Yeiser, B. G., Wiley, T. R., Poulakis, G. R., Stevens, P. W., and Heupel, M. R.: Environmental influences on the spatial ecology of juvenile smalltooth sawfish (Pristis pectinata): Results from acoustic monitoring, Plos One, 6, 1-12, 2011.

Smith, V. H.: Nitrogen, phosphorus, and nitrogen fixation in lacustrine and estuarine ecosystems, Limnol. Oceanogr., 35, 1852 1859, 1990.

Smith, V. H.: Responses of estuarine and coastal marine phytoplankton to nitrogen and phosphorus enrichment, Limnol. Oceanogr., 51, 377-384, 2006.

Smith, S. V. and Hollibaugh, J. T.: Water, salt, and nutrient exchanges in San Francisco Bay, Limnol. Oceanogr., 51, 504-517, 2006.

Smith, S. V., Swaney, D. P., Talaue-McManus, L., Bartley, J. D., Sandhei, P. T., McLaughlin, C. J., Dupra, V. C., Crossland, C. J., Buddemeier, R. W., Maxwell, B. A., and Wulff, F.: Humans, hydrology, and the distribution of inorganic nutrient loading to the ocean, Bioscience, 53, 235-245, 2003.

Smith, S. V., Buddmeier, R. W., Wulff, F., Swaney, D. P.: C, N, $\mathrm{P}$ fluxes in the coastal zone, edited by Crossland, C. J., Kremer, H. H., Lindeboom, H. J., Marshall-Crossland, J. I, and Le Tissier, M. D. A.: Coastal Fluxes in the Anthropocene. The LandOcean Interactions in the Coastal Zone Project of the International Geosphere-Biosphere Programme, Spring, Berlin, Heidelberg, Chapter 3, 96-143. 2005.

Smith, V. H., Joye, S. B., and Howarth, R. W.: Eutrophication of freshwater and marine ecosystems, Limnol. Oceanogr., 5, 351355, 2006. 
Swaney, D. P., Smith, S. V., and Wulff, F.: The LOICZ Biogeochemical Modeling Protocol and its Application to Estuarine Ecosystems in: Estuarine and Coastal Ecosystem Modeling, edited by: Baird, D. and Mehta, A., Academic Press, Amsterdam, Chapter 9, 135-160, 2011.

Talaue-McManus, L., Smith, S. V., and Buddemeier, R. W.: Biophysical and socio-economic assessments of the coastal zone: the LOICZ approach, Ocean Coast. Manag., 46, 323-333, 2003.

Tolley, S. G., Evans, J. T., Burghart, S. E., Winstead, J. T., and Volety, A. K.: Role of freshwater inflow and salinity on population regulation in the hydrozoan inquiline symbiont Eutima sp., Bull. Mar. Sci., 86, 625-636, 2010.

United States Army: Annual Report of the Chief of Engineers, War Department Document Number 493, Part 1, Government Printing Office, Washington, DC, 1915.
Webster, I. T., Smith, S. V., and Parslow, J. S.: Implications of spatial and temporal variation for biogeochemical budgets of estuaries, Estuaries, 23, 341-350, 2000.

Wosten, J. H. M., de Willigan, P., Tri, N. H., Lien, T. V., and Smith, S. V.: Nutrient dynamics in mangrove areas of the Red River Estuary in Vietnam, Estuar. Coast. Shelf Sci., 57, 65-72, 2003.

Wulff, F., Eyre, B., and Johnstone, R.: Nitrogen versus phosphorus limitation in a subtropical embayment (Moreton Bay, Australia): Implications for management, Ecol. Modell., 222, 120130, 2011.

Yamamoto, T., Hiraga, N., Takeshita, K., and Hashimoto, T.: An estimation of net ecosystem metabolism and net denitrification of the Seto Inland Sea, Japan, Ecol. Modell., 215, 55-68, 2008. 